\title{
NGF-Enhanced Vasculogenic Properties of Epithelial Ovarian Cancer Cells Is Reduced by Inhibition of the COX-2/PGE 2 Signaling Axis
}

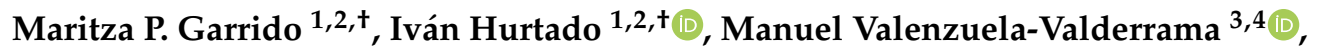 \\ Renato Salvatierra ${ }^{1}$, Andrea Hernández ${ }^{1}$, Margarita Vega ${ }^{1,2}$, Alberto Selman ${ }^{2}$, \\ Andrew F. G. Quest ${ }^{4,5, *(D)}$ and Carmen Romero ${ }^{1,2,4, *}$ \\ 1 Laboratorio de Endocrinología y Biología de la Reproducción, Hospital Clínico Universidad de Chile, \\ Santiago 8380456, Chile; mgarrido@hcuch.cl (M.P.G.); ihurtado@hcuch.cl (I.H.); \\ rsalvatierratm@gmail.com (R.S.); ahernandezj@hcuch.cl (A.H.); mvega@med.uchile.cl (M.V.) \\ 2 Departamento de Obstetricia y Ginecología, Facultad de Medicina, Universidad de Chile, Santiago 8380453, \\ Chile; selmanalberto@gmail.com \\ 3 Laboratorio de Microbiología Celular. Instituto de Investigación e Innovación en Salud. Facultad de \\ Ciencias de la Salud, Universidad Central de Chile, Santiago 8320000, Chile; manuel.valenzuela@ucentral.cl \\ 4 Advanced Center for Chronic Diseases (ACCDIS), Santiago 8380000, Chile \\ 5 Laboratorio de Comunicaciones Celulares, Centro de estudios en Ejercicio, Metabolismo y Cáncer (CEMC), \\ Facultad de Medicina, Universidad de Chile, Santiago 8380453, Chile \\ * Correspondence: aquest@med.uchile.cl (A.F.G.Q.); cromero@hcuch.cl (C.R.) \\ $\dagger$ These authors contributed equally to this work.
}

Received: 28 October 2019; Accepted: 19 November 2019; Published: 7 December 2019

\begin{abstract}
Epithelial ovarian cancer (EOC) is a lethal gynecological neoplasia characterized by extensive angiogenesis and overexpression of nerve growth factor (NGF). Here, we investigated the mechanism by which NGF increases vascular endothelial growth factor (VEGF) expression and the vasculogenic potential of EOC cells, as well as the contribution of the cyclooxygenase 2/prostaglandin $\mathrm{E}_{2}\left(\mathrm{COX}-2 / \mathrm{PGE}_{2}\right)$ signaling axis to these events. EOC biopsies and ovarian cell lines were used to determine COX-2 and $\mathrm{PGE}_{2}$ levels, as well as those of the potentially pro-angiogenic proteins c-MYC (a member of the Myc transcription factors family), survivin, and $\beta$-catenin. We observed that COX-2 and survivin protein levels increased during EOC progression. In the EOC cell lines, NGF increased the COX-2 and PGE $_{2}$ levels. In addition, NGF increased survivin, c-MYC, and VEGF protein levels, as well as the transcriptional activity of c-MYC and $\beta$-catenin/T-cell factor/lymphoid enhancer-binding factor (TCF-Lef) in a Tropomyosin receptor kinase A (TRKA)-dependent manner. Also, COX-2 inhibition prevented the NGF-induced increases in these proteins and reduced the angiogenic score of endothelial cells stimulated with conditioned media from EOC cells. In summary, we show here that the pro-angiogenic effect of NGF in EOC depends on the COX-2/PGE2 signaling axis. Thus, inhibition COX-2/PGE2 signaling will likely be beneficial in the treatment of EOC.
\end{abstract}

Keywords: NGF; epithelial ovarian cancer; COX-2/PGE ; vasculogenesis; VEGF; c-MYC; survivin; beta-catenin

\section{Introduction}

Epithelial ovarian cancer (EOC) is the eighth largest cause of death by cancer in women worldwide [1,2]. This pathology is characterized by non-specific symptoms and, therefore, is diagnosed at later stages, resulting in poor survival rates [3-6]. One important characteristic of this neoplasm is the high extent of angiogenesis that facilitates rapid tumor growth and dissemination [7]. The most 
studied angiogenic factor, vascular endothelial growth factor (VEGF), is overexpressed in EOC $[7,8]$. Our group has shown that nerve growth factor (NGF) and its high affinity receptor tropomyosin receptor kinase A (TRKA) increase during EOC progression [9], activating phosphoinositide 3-kinase/ protein kinase $\mathrm{B}$ (PI3K/AKT) and mitogen-activated protein kinase /extracellular signal-regulated kinase (MAPK/ERK) signaling pathways, resulting in enhanced tumor growth [10]. In addition, NGF represents both a direct and indirect angiogenic factor [9,11,12], as NGF increases VEGF levels in EOC cells $[9,11]$ and also binds to the high affinity receptor TRKA in endothelial cells, thereby increasing their proliferation, migration, and vasculogenesis $[9,12]$.

To shed light on the mechanism(s) by which NGF increases VEGF expression in EOC cells, we studied some known regulators of VEGF expression, which include cyclooxygenase 2/prostaglandin $\mathrm{E}_{2}$ (COX-2/PGE ${ }_{2}$ [13-16], survivin (BIRC5) [17,18], the $\beta$-catenin/ T-cell factor/lymphoid enhancer-binding factor (TCF-Lef) transcription complex $[17,19,20]$, and the c-MYC transcription factor [21,22]. COX-2 is a key enzyme in the synthesis of prostaglandins, including $\mathrm{PGE}_{2}$, the most commonly and ubiquitously produced derivative $[23,24]$. COX-2 can be induced by various stimuli and plays a key role in inflammation [23-25] and cancer progression [26-29]. Different in vitro studies have demonstrated that COX-2 and $\mathrm{PGE}_{2}$ induce VEGF secretion in an ERK-dependent manner [15,30-32]. On the other hand, EOC is characterized by overexpression of oncogenic proteins, such as c-MYC and $\beta$-catenin, which are associated with poor prognosis [33-35] and are known to increase the transcription of VEGF and survivin [36-38]. Interestingly, a positive loop between $\beta$-catenin/TCF-Lef, COX-2, and VEGF has been described in melanoma and gastric cells involving the PI3K/AKT signaling pathway $[17,39]$. All these regulatory mechanisms are likely to cooperate in promoting angiogenesis in EOC.

Previous findings indicate that NGF/TRKA increase c-MYC and VEGF expression in EOC explants [10]. Therefore, we evaluated whether NGF stimulation enhances COX-2 protein levels and $\mathrm{PGE}_{2}$ in EOC cells, and also, the expression of the pro-angiogenic proteins c-MYC, $\beta$-catenin, survivin, and VEGF. In addition, we evaluated the dependence of NGF-effects on signaling via the COX-2/PGE 2 axis.

Our results show that COX-2 and survivin protein levels increase during EOC progression, being higher in advanced stages of the disease. NGF stimulation of EOC cells (A2780, SKOV3, OVCAR3, and OV90) increases COX-2 and $\mathrm{PGE}_{2}$ levels, the expression of the pro-angiogenic proteins survivin, c-MYC, and VEGF, as well as the transcriptional activity of c-MYC and $\beta$-catenin/TCF-Lef. Direct stimulation of EOC cells with $\mathrm{PGE}_{2}$ yielded comparable results to those observed with NGF. Moreover, in the presence of a COX-2 inhibitor, NGF-induced effects were prevented. These results suggest that the NGF-induced expression of pro-angiogenic proteins and the angiogenic potential of EOC cells depend on signaling via the COX-2/ $\mathrm{PGE}_{2}$ axis.

\section{Results}

\subsection{COX-2 Expression Increases During EOC Progression}

Samples of well-differentiated epithelial ovarian cancer (EOC I), moderately differentiated epithelial ovarian cancer (EOC II), and poorly differentiated epithelial ovarian cancers (EOC III) were grouped as EOC, whereas benign and borderline tumors were grouped as ovarian tumors (OvTu). Of note, COX-2 protein and its messenger RNA (mRNA) levels were significantly higher in the EOC group as compared to the inactive ovarian epithelium (IOV) group $(p<0.05$; Figure $1 \mathrm{~A}-\mathrm{D})$. Likewise, COX-2 protein levels were higher in the EOC group compared with the IOV group $(p<0.05$; Figure 1C). Immunohistochemical analysis identified COX-2 in epithelial cell monolayers and transformed epithelial cells, whereby staining was mainly cytoplasmic (Figure 1E). Additionally, during EOC progression, a substantial increase in COX-2 levels was observed, and this increase became significant at the borderline tumor stage (BorT) $(p<0.01$ vs. IOV; Figure 1E). 
A

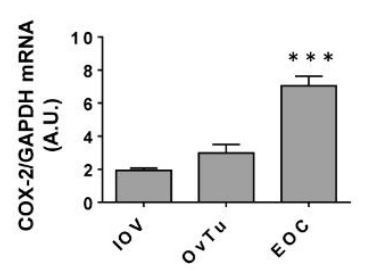

E

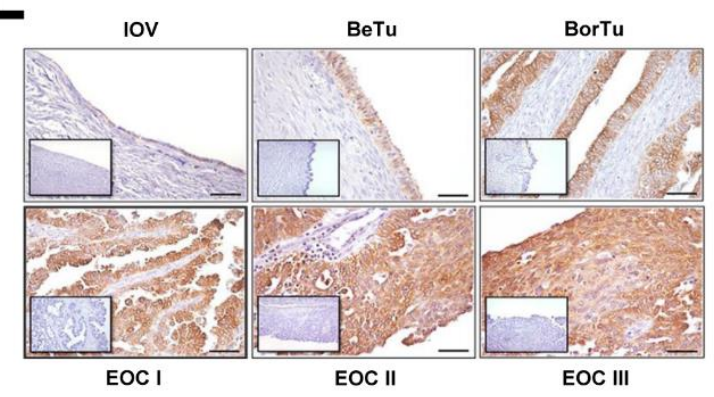

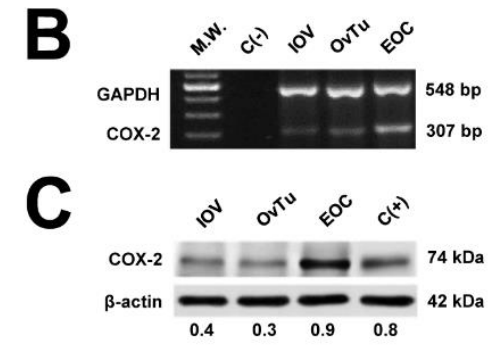

D

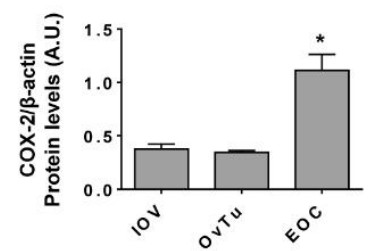

$\mathbf{F}$
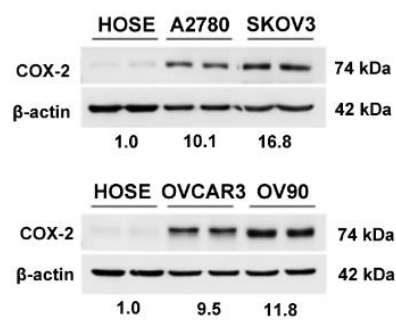

G
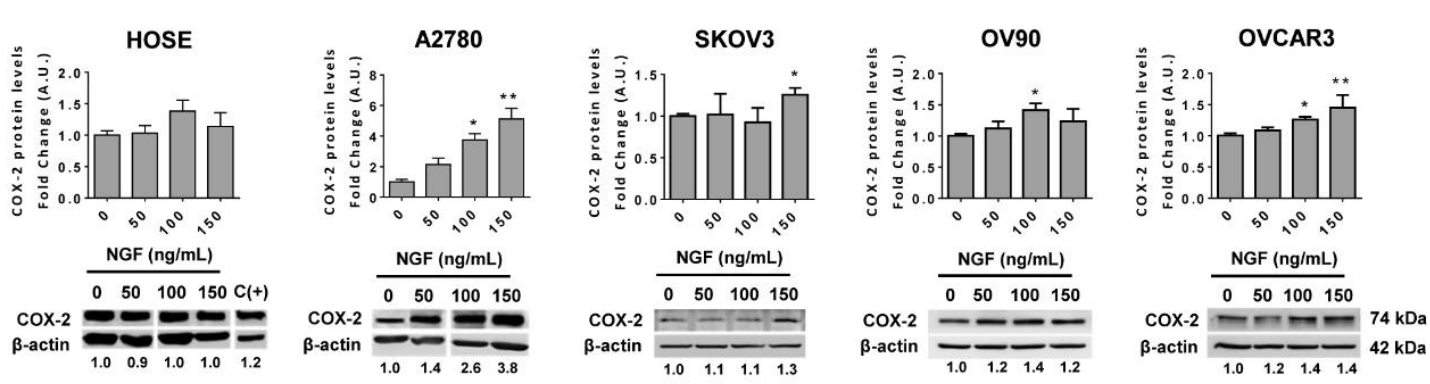

H
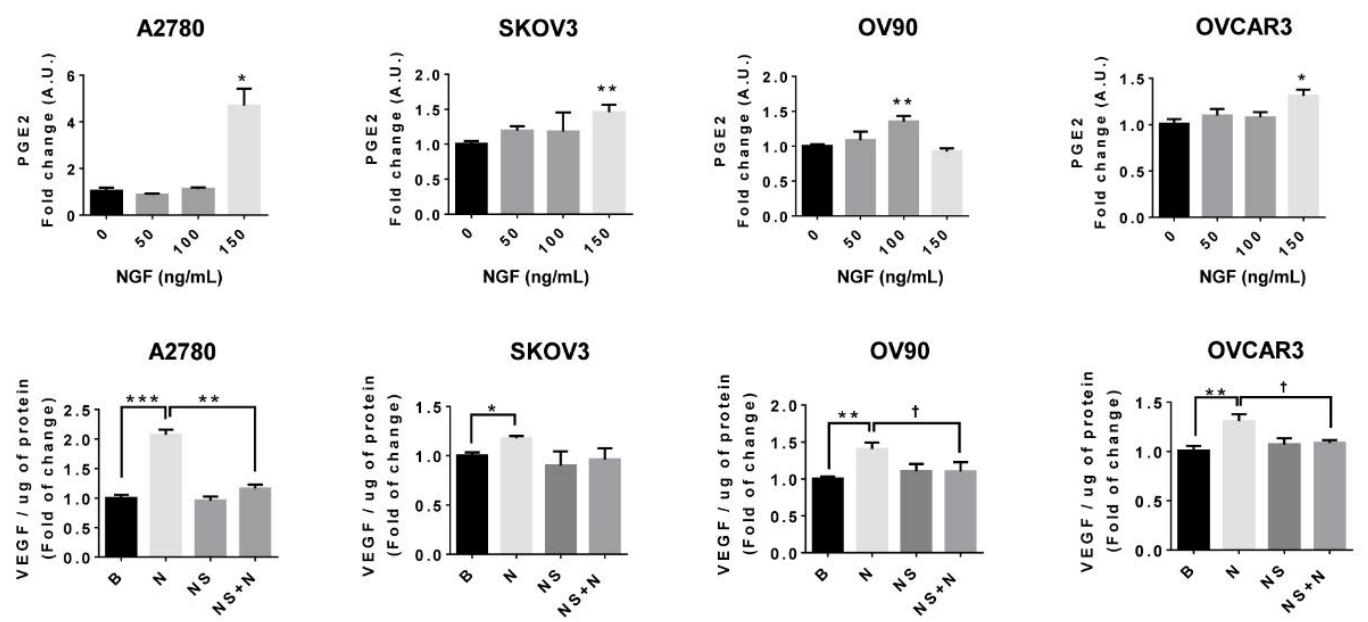

Figure 1. Cyclooxygenase 2 (COX-2) increases during epithelial ovarian cancer (EOC) progression and upon nerve growth factor (NGF) stimulation of EOC cell lines. (A) Semi-quantitative analysis of COX-2 mRNA levels in inactive ovarian epithelium (from post-menopausal women, inactive ovarian epithelium $(\mathrm{IOV})$ ), ovarian tumors (OvTu) and epithelial ovarian cancers (EOC). $n=3,15$, and 10 respectively. *** $=p<0.001$ with respect to IOV. (B) Representative image of agarose gel showing COX-2 products in ovarian samples. M.W: molecular weight. C(-): negative control. (C) Representative western-blot of COX-2 protein levels in ovarian tissues (with the respective COX-2/ $\beta$-actin ratios). (D) Quantification of COX-2 protein levels in ovarian biopsies evaluated by western blotting. $n=4,9$, and 8 for IOV, OvTu, and EOC, respectively. ${ }^{*}=p<0.05$ with respect to IOV. (E) Immunohistochemical analysis of COX-2 in IOV, OvTu sub-classified into benign tumor (BeT) and borderline tumor (BorT). EOCs were sub-classified into well differentiated epithelial ovarian cancer (EOC I), moderately differentiated epithelial ovarian cancer (EOC II), and poorly differentiated epithelial ovarian cancer (EOC III). Images were obtained at 
400× magnification. Negative control: lower left corner. Scale bar: $50 \mu \mathrm{m}$. Right: Quantitative analysis of COX-2 immunostaining in ovarian tissues. $n=4$ for IOV and $n=6$ or more for the other groups. ${ }^{* *}=p<0.01$ and $^{* * *}=p<0.001$ with respect to IOV. (F) Basal COX-2 immunodetection in ovarian cell lines HOSE, A2780, SKOV3, OV90, and OVCAR3 by western blotting (normalized to the mean COX-2/ $\beta$-actin ratio). (G) COX-2 protein levels after NGF stimulation $(50,100$, and $150 \mathrm{ng} / \mathrm{mL})$ for $2 \mathrm{~h}$ in HOSE and A2780 cells or $8 \mathrm{~h}$ in SKOV3, OV90, and OVCAR3 cells (with the COX-2/ $\beta$-actin ratios). C(+): positive control described in the methodology section. $n=4$ or more for each condition. ${ }^{*}=p<0.05$, ${ }^{* *}=p<0.01(\mathbf{H})$ Prostaglandin E2 in culture supernatants of ovarian cell lines after NGF stimulation. $n=4$ or 5 in duplicate. ${ }^{*}=p<0.05$ (I) Vascular endothelial growth factor (VEGF) protein levels in culture supernatants of EOC cells treated with NGF or the COX-2 inhibitor NS398 (as described in methodology section). $\mathrm{B}=$ basal condition (without stimuli); $\mathrm{N}=\mathrm{NGF}$; NS $=$ NS398. $n=4$ or 6 in duplicate. ${ }^{*}=p<0.05,{ }^{* *}=p<0.01$ and ${ }^{* *}=p<0.001$ with respect to baseline condition or as indicated (Kruskal-Wallis test and Dunn's post-test). $+p<0.05$ with respect to baseline condition or as indicated (Mann-Whitney test). Results are expressed as the mean \pm standard error of the mean (SEM).

\subsection{NGF Increases COX-2 Expression in EOC Cells}

Basal COX-2 levels in EOC cell lines (A2780, SKOV3, OV90, and OVCAR3 cell lines) were higher than in non-tumoral human ovarian surface epithelium (HOSE) cells (Figure 1F). Upon stimulating with NGF (100 and $150 \mathrm{ng} / \mathrm{mL}$ ), significant increases in COX-2 protein levels were observed in EOC cells, but not in non-tumoral HOSE cells ( $p<0.05$ and $p<0.01$; Figure 1G and Figure S1). Because transforming growth factor beta (TGF- $\beta$ ) has been shown to induce $\mathrm{PGE}_{2}$ in granulose cells [40], it was used as a positive control. A significant increase in COX-2 mRNA and protein levels was detected in A2780 cells stimulated with 15 or $20 \mathrm{ng} / \mathrm{mL}$ of TGF- $\beta 1(p<0.05$; Figure S2A-D). Furthermore, the increase in COX-2 protein levels in A2780 cells triggered by TGF- $\beta 1$ correlated with accumulation of $\mathrm{PGE}_{2}$ in culture supernatants $(p<0.05$; Figure $\mathrm{S} 2 \mathrm{E}, \mathrm{F})$.

\subsection{NGF Increases $P G E_{2}$ Secretion by EOC Cells}

To determine whether the COX-2 increase observed in EOC cells lead to enhanced secretion of prostaglandin $\mathrm{E}_{2}$, levels of these prostanoids were determined in the conditioned culture media of ovarian cells. NGF stimulation induced an increase in the presence of such prostaglandins in the cell culture medium of all EOC cell lines $(p<0.05$ in A2780 and OVCAR3 cells, $p<0.01$ in SKOV3 and OV90 cells; Figure 1H). The mean increase was higher in A2780 cell lines, which may be because baseline levels of $\mathrm{PGE}_{2}$ in these cells are lower compared with the other EOC cell lines (Figure S3A). Alternatively, the increase in $\mathrm{PGE}_{2}$ induced by NGF was observed only in EOC cells. NGF treatment of non-tumoral HOSE cells did not increase significantly PGE $_{2}$ levels in the conditioned medium of these cells (Figure S4).

\subsection{Role of COX/2-PGE 2 in VEGF Secretion by Ovarian Cells}

Previous results demonstrated that NGF increases VEGF expression in both EOC tissue explants and A2780 cells $[9,11]$. Thus, considering that in other cancers $\mathrm{PGE}_{2}$ is known to modulate VEGF levels [13-16], we evaluated here whether such NGF-mediated increases in VEGF were connected to the COX-2/PGE 2 signaling pathway. As Figure 1 I shows, NGF treatment (100 or $150 \mathrm{ng} / \mathrm{mL}$ ) increased VEGF protein levels in all EOC cell lines $(p<0.05, p<0.01$, and $p<0.001$ for SKOV3, OV90/OVCAR3, and A2780, respectively). Importantly, the increase in VEGF triggered by NGF was reduced significantly by prior treatment of cells with a specific COX-2 inhibitor (NS, $20 \mu \mathrm{M})(p<0.05$ in OV90 and OVCAR3 cells; and $p<0.01$ in A2780). These results are consistent with the notion that COX-2 inhibition blocks the NGF-induced increase in $\mathrm{PGE}_{2}$ in the EOC cell line A2780 (Figure S3B), which suggests that NGF increases VEGF levels in a COX2/PGE 2 -dependent manner in EOC cells. 
Because many proteins and transcription factors regulate VEGF expression [17,18], we sought to identify possible mechanisms by which NGF-COX-2/PGE 2 signaling increased VEGF levels in ovarian cells.

\subsection{Survivin Levels Increase During EOC Progression}

Survivin is an oncogenic protein that is associated with poor prognosis in ovarian cancer [41] and reportedly increases VEGF levels in in vitro models $[17,18]$. Indeed, for EOC and OvTu samples, higher levels of survivin were observed by immunohistochemistry (IHQ) compared to IOV samples $(p<0.001$ and $p<0.0001$, respectively; Figure 2A,B). Similar results were obtained when survivin protein levels in EOC samples were evaluated by western blotting ( $p<0.01$; Figure $2 \mathrm{C}, \mathrm{D})$. In both cases, increases were associated with EOC progression (Figure S5). In addition, basal survivin levels assessed in ovarian cell lines (Figure 2E), revealed that EOC cell lines had higher levels of survivin compared with non-tumoral HOSE cells. These findings are consistent with the biopsy results, confirming that these cell lines represent appropriate models to study survivin in the context of EOC.

A

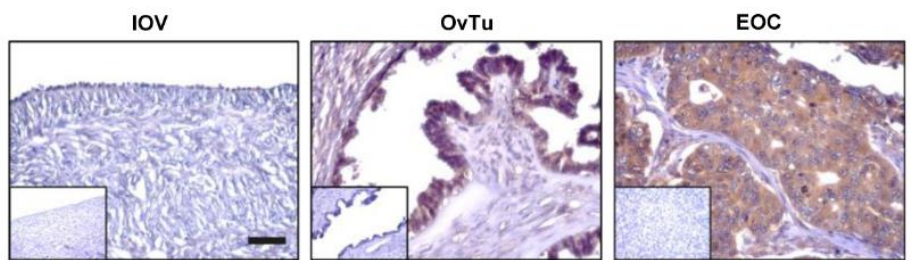

B
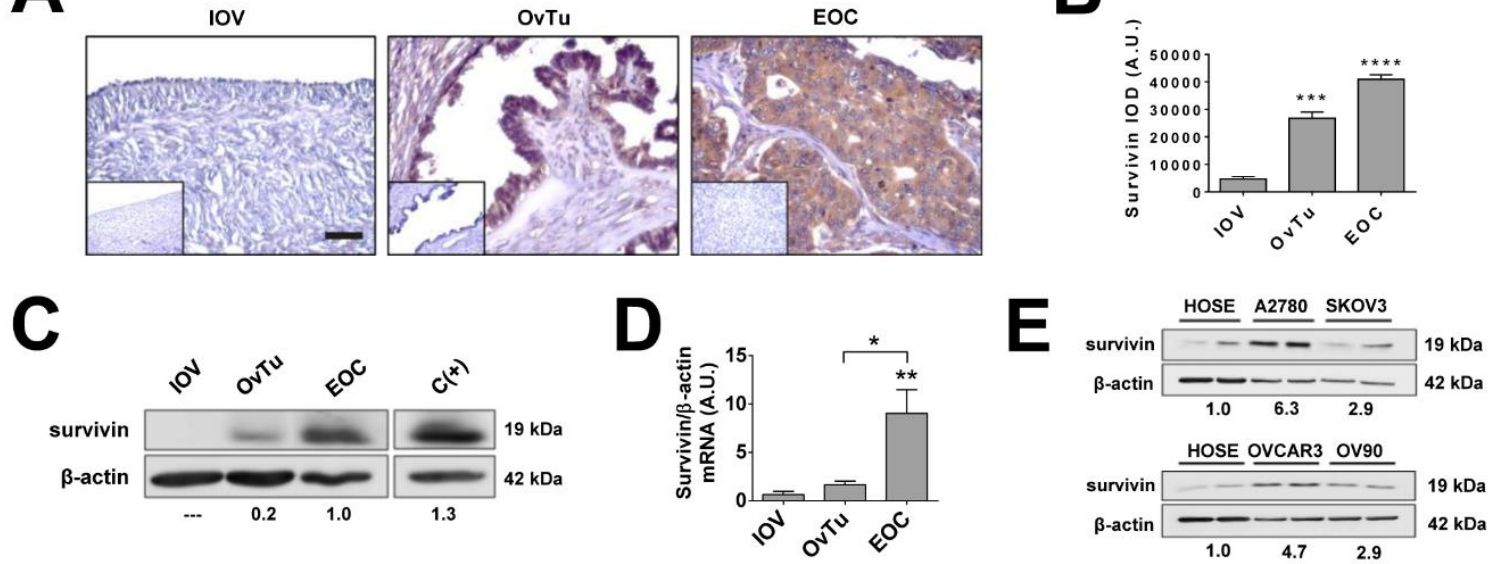

$\mathbf{F}$
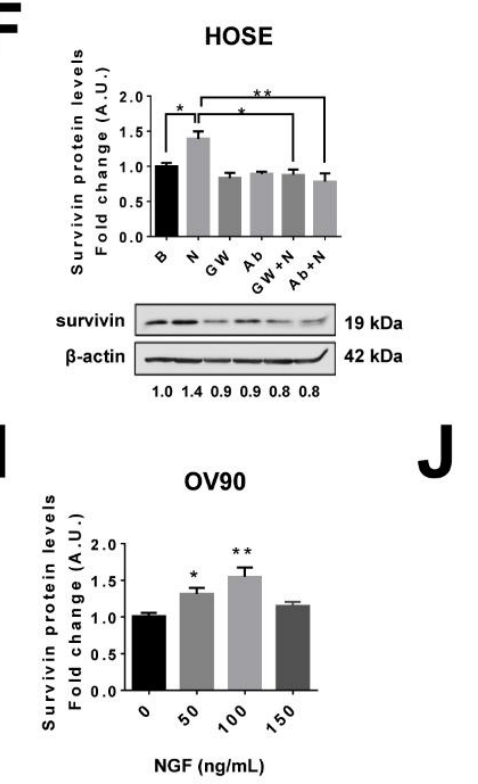

G

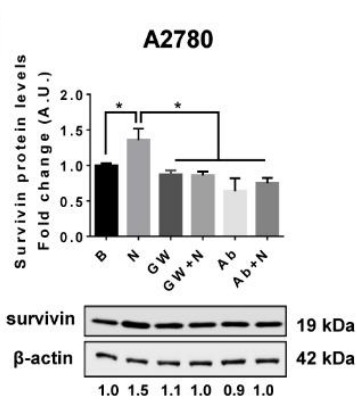

OVCAR3

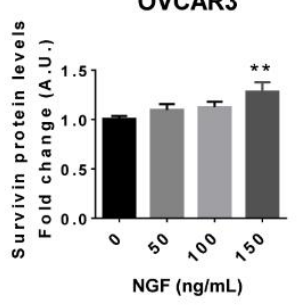

H

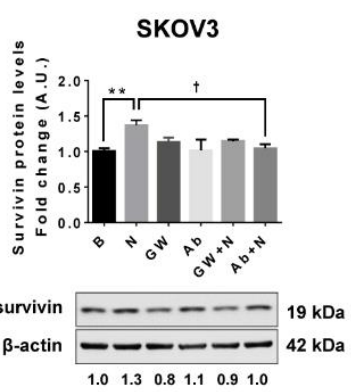

OV90

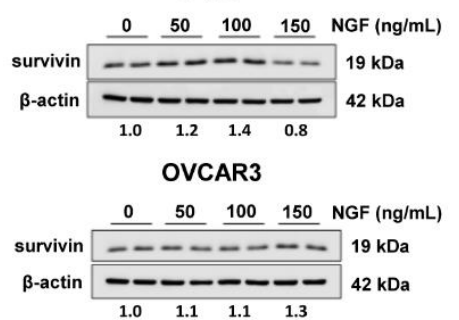

Figure 2. Survivin levels increase during EOC progression and following NGF stimulation of EOC cells. (A) Representative images of immunohistochemical detection of survivin in inactive ovarian epithelium (OVI, $n=5)$, epithelial ovarian tumors $(\mathrm{OvTu} ; n=6)$, and epithelial ovarian cancer (EOC, 
$n=12)$ tissue. Scale bar: $50 \mu \mathrm{m}$. (B) Semi-quantification of survivin immunodetection by immunohistochemistry. (C) Representative western blot of survivin protein levels in ovarian biopsies (with the survivin/ $\beta$-actin ratios). (D) Quantification of survivin levels detected in extracts of ovarian tissues by western blotting, $n=4$ for IOV, $n=11$ for OvTu, and $n=15$ for EOC. (E) Representative images of baseline levels of survivin evaluated by western blotting in ovarian cell lines (normalized to mean survivin/ $\beta$-actin ratio). (F-H) survivin protein levels in ovarian cells lines either stimulated with NGF (N; 100 or $150 \mathrm{ng} / \mathrm{mL}$ as described in the methodology section), or treated with the neutralizing antibody against-NGF (Ab, $5 \mu \mathrm{g} / \mathrm{mL}$ ) or the pharmacological TRKA inhibitor GW441756 (GW, $20 \mathrm{nM})$ for $2 \mathrm{~h}$ (HOSE and SKOV3 cells), $8 \mathrm{~h}$ (OV90 and OVCAR3), or $24 \mathrm{~h}$ (A2780 cells), respectively (with the survivin/ $\beta$-actin ratio). $n=4$ or more in duplicate per condition. (I-K) survivin protein levels following NGF stimulation in OV90 and OVCAR3 cells (normalized to average survivin/ $\beta$-actin ratio). $n=4$ or more in duplicate per condition. ${ }^{*}=p<0.05 ;^{* *}=p<0.01{ }^{* * *}=p<0.001$, and ${ }^{* * * *}=p<0.0001$ with respect to baseline condition or as indicated (Kruskal-Wallis test and Dunn's post-test). $+=p<0.05$ as indicated (Mann-Whitney test). Results are expressed as the mean \pm standard error of the mean (SEM).

\subsection{NGF Increases Survivin Levels in Epithelial Ovarian Cells}

NGF stimulation of ovarian cell lines significantly increased survivin protein levels compared with the baseline condition ( $p<0.05$ in HOSE and A2780 cells; $p<0.01$ in SKOV3, OV90, and OVCAR3; Figure 2F-K). Importantly, this increase was blocked by the specific TRKA inhibitor GW441756 or an NGF neutralizing antibody (Figure 2F-H), indicating that the NGF- mediated effect was mediated by the high-affinity NGF receptor TRKA.

\subsection{NGF Increases $\beta$-Catenin-TCF-Lef Transcriptional Activity in EOC Cells}

Association of $\beta$-catenin with TCF-Lef transcription family members in the nucleus generates a complex that increases the transcription of many oncogenic proteins and factors, including VEGF $[17,19,20]$. Basal levels of $\beta$-catenin did not differ substantially between the EOC cell lines (Figure 3A) and NGF stimulation of EOC cells induced a modest increase in $\beta$-catenin protein levels in SKOV3 and OV90 cells (Figure 3B and Figure S6). However, following NGF stimulation, higher cytoplasmic and/or nuclear levels of $\beta$-catenin were detected (Figure 3C). Then $\beta$-catenin/TCF-Lef reporter assays were performed in EOC cell lines. We observed that NGF enhanced $\beta$-catenin/TCF-Lef transcriptional activity in the four EOC cell lines studied ( $p<0.05$; Figure 3D). Furthermore, the NGF-dependent increase in $\beta$-catenin/TCF-Lef transcriptional activity in A2780 cells was blocked by the specific TRKA inhibitor GW441756 ( $p<0.05$; Figure S7A). Taken together, these results show that NGF/TRKA signaling augments the transcriptional activity of $\beta$-catenin/TCF-Lef in EOC cells.

\subsection{NGF Increases c-MYC Levels and Its Transcriptional Activity in EOC Cells}

c-MYC is an important proto-oncogene and previous reports have shown that c-MYC activation can increase VEGF expression [21,22]. As determined by western blotting shown in Figure 4A, basal c-MYC levels were notably different in ovarian cell lines, being elevated in A2780 and OVCAR3 cells and essentially undetectable in HOSE cells. In addition, the results showed that NGF stimulation increased c-MYC protein levels in all ovarian cell lines used $(p<0.05$ in SKOV3 and OVCAR3 cells, $p<0.01$ in A2780 and OV90 cells, and $p<0.001$ in HOSE cells; Figure 4B-D). Importantly, the NGF-mediated increase in c-MYC levels was prevented either by addition of the TRKA inhibitor (GW441756) or an NGF neutralizing antibody (Figure 4B,C). Moreover, NGF stimulation induced nuclear accumulation of c-MYC in EOC cells ( $p<0.05$ in SOV3 and OVCAR3 cells; $p<0.01$ in A2780 and OV90 cells; Figure 4E), as well as increased c-MYC transcriptional activity $(p<0.05$; Figure $4 \mathrm{~F})$ in a TRKA-dependent manner (Figure S7B). These results confirm in cell lines the previous reports from our group, showing that NGF stimulates c-MYC expression in EOC explants [10]. 
A

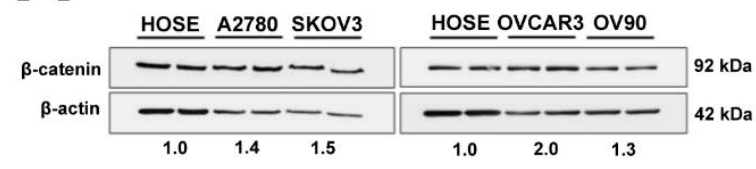

B
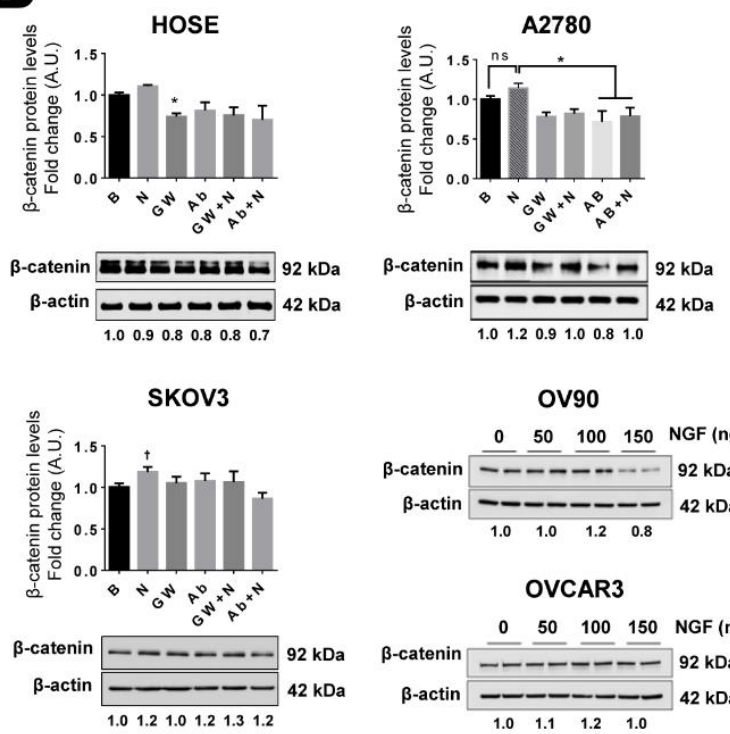

OV90

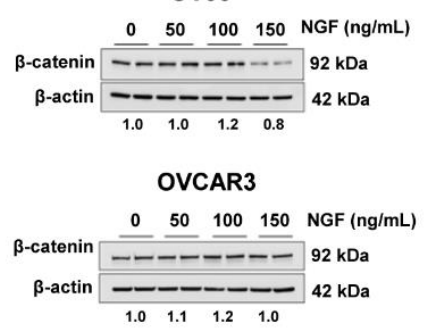

D
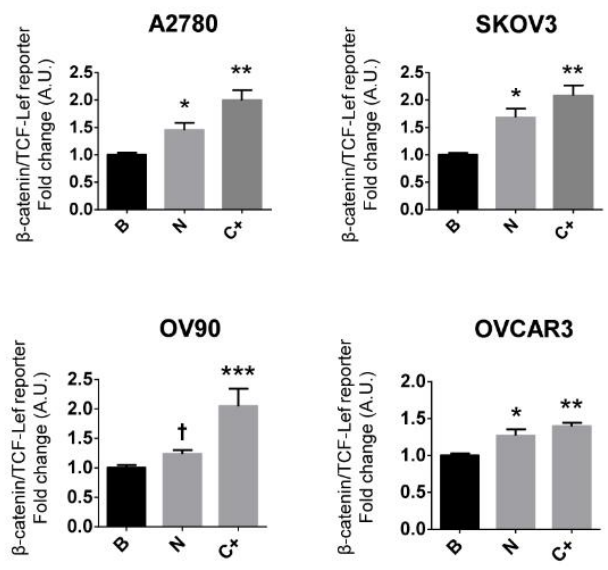

C
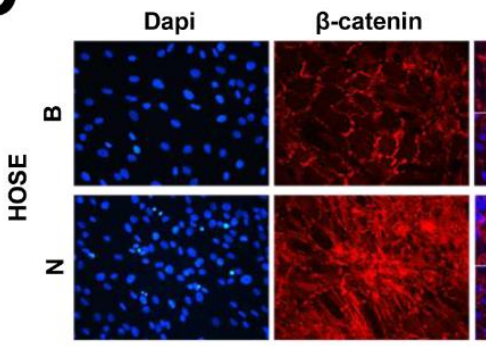

merge
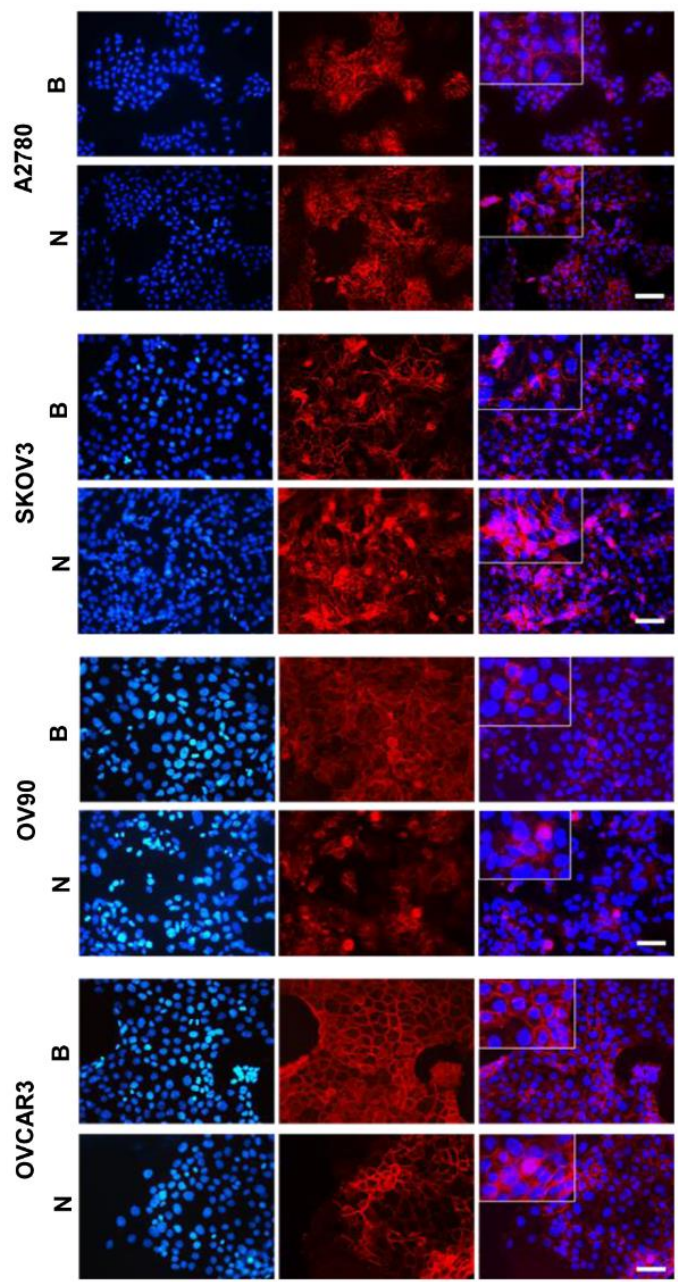

Figure 3. NGF increases $\beta$-catenin/ T-cell factor/lymphoid enhancer-binding factor (TCF-Lef) transcriptional activity in EOC cells. Ovarian cell lines were stimulated with NGF (N, 100 or $150 \mathrm{ng} / \mathrm{mL}$, as described), the neutralizing antibody against-NGF (Ab, $5 \mu \mathrm{g} / \mathrm{mL}$ ), or the pharmacological TRKA inhibitor GW441756 (GW, $20 \mathrm{nM}$ ) for $2 \mathrm{~h}$ (HOSE, A2780, and SKOV3 cells) and $8 \mathrm{~h}$ (OV90 and OVCAR3). (A) Western blots showing baseline levels of survivin in ovarian cell lines (normalized to mean $\beta$-catenin $/ \beta$-actin ratio). (B) $\beta$-catenin protein levels in extracts of HOSE, A2780, SKOV3, OV90, and OVCAR3 cells analyzed by western blotting (with the $\beta$-catenin/ $\beta$-actin ratios). $n=4$ or more in duplicate. (C) Immunofluorescence of $\beta$-catenin in ovarian cell lines either stimulated with NGF $(\mathrm{N})$ or without stimulation (B, basal) to assess the cellular localization of $\beta$-catenin. Dapi: 4',6-diamidino-2-phenylindole (nuclear fluorescent stain). Magnification: 400×. Bar $=50$ um. (D) $\beta$-catenin/TCF-Lef reporter analysis of extracts from EOC cells stimulated with NGF ( $n, 100$ or $150 \mathrm{ng} / \mathrm{mL}$ ) for $24 \mathrm{~h}$. C+: positive control ( $\mathrm{LiCl} 15 \mathrm{mM}$ for $24 \mathrm{~h}) . n=4$ or more. ${ }^{*} p<0.05,{ }^{* *} p<0.01$, and ${ }^{* * *} p<0.001$, with respect to the baseline condition or as indicated (Kruskal-Wallis test and Dunn's post-test). $+p<0.05$, with respect to the baseline condition or as indicated (Mann-Whitney test). Results are expressed as the mean \pm standard error of the mean (SEM). 


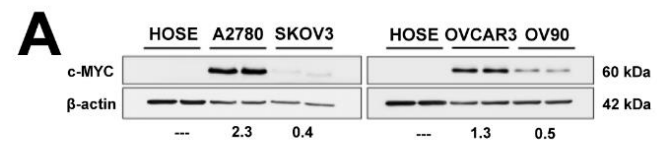

E
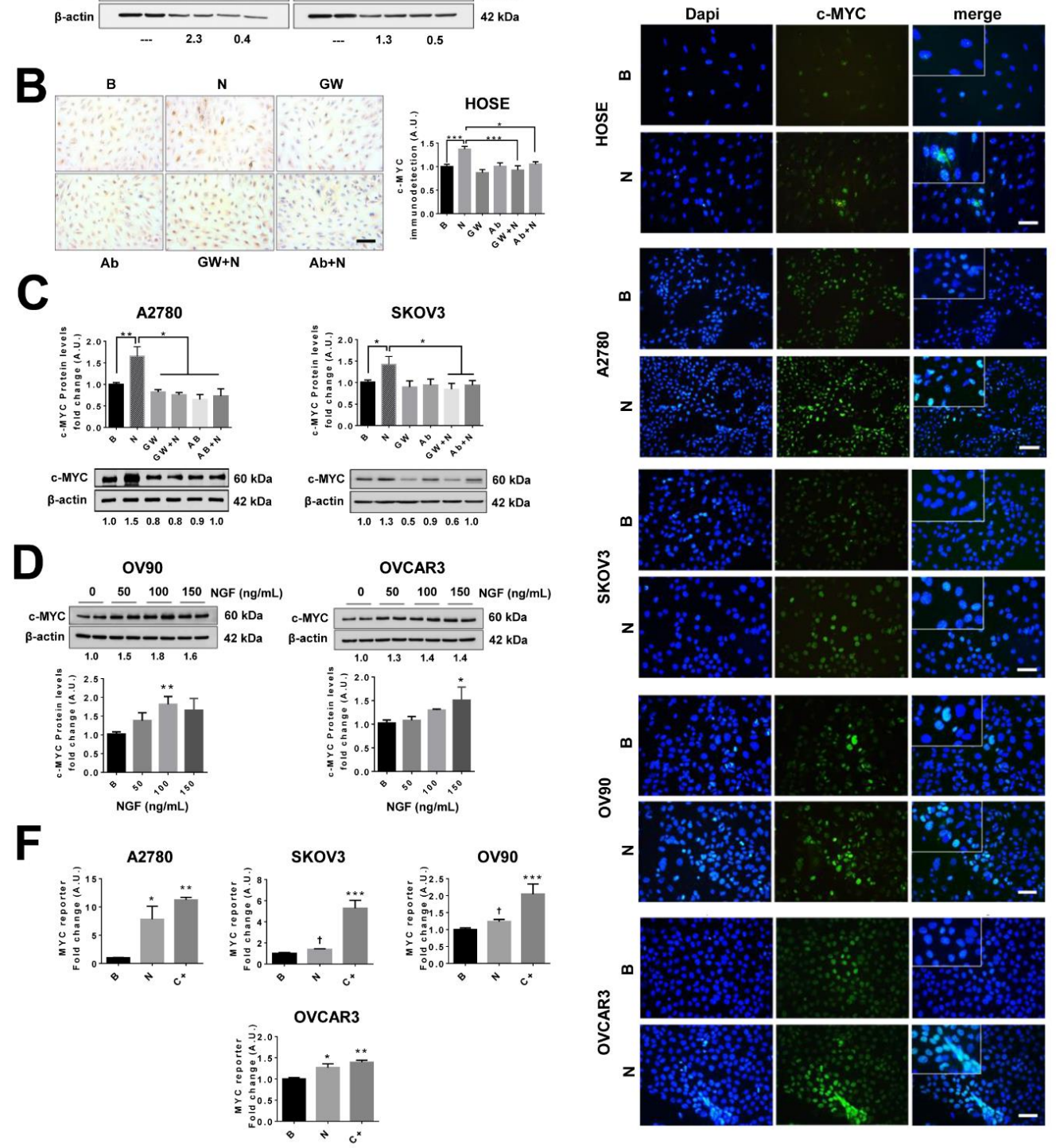

Figure 4. NGF increases c-MYC protein levels and transcriptional activity in EOC cells. Ovarian cells were stimulated with NGF (N, 100 or $150 \mathrm{ng} / \mathrm{mL})$, the neutralizing antibody against-NGF $(\mathrm{Ab}, 5 \mu \mathrm{g} / \mathrm{mL})$, or the pharmacological TRKA inhibitor GW441756 (GW, $20 \mathrm{nM}$ ) for $2 \mathrm{~h}$ (HOSE. A2780 and SKOV3 cells) and $8 \mathrm{~h}$ (OV90 and OVCAR3 cells). (A) Representative western blot showing baseline levels of c-MYC in ovarian cell lines (compared with average c-MYC/ $\beta$-actin ratio). (B) Immunodetection of c-MYC by immunocytochemistry and semi-quantification in HOSE cells. Bar: $100 \mu \mathrm{m} . n=4$; eight pictures per condition were analyzed. (C,D) c-MYC protein levels assessed by western blotting and quantification (with the $\beta$-catenin/ $\beta$-actin ratio), $n=4$ in duplicate. (E) c-MYC immunodetection in ovarian cells either stimulated with NGF $(n)$ or without stimulation (B, basal) to assess the abundance and cellular localization. Magnification: $400 \times$. Bar $=50 \mu \mathrm{m}$. (F) MYC reporter assay of extracts from EOC cells stimulated with NGF $(n)$ for $24 \mathrm{~h}$. C+: positive control (cell co-transfected with reporter construct and c-MYC plasmid). $n=4$ or more. ${ }^{*}=p<0.05,{ }^{* *}=p<0.01$, and ${ }^{* *}=p<0.001$, with respect to baseline condition or as indicated (Kruskal-Wallis test and Dunn's post-test). $\dagger=p<0.05$ with respect to baseline condition (Mann-Whitney test). Results are expressed as the mean \pm standard error of the mean (SEM). 
2.9. Inhibition of the COX-2/PGE 2 Axis Prevents NGF Stimulated Increases in Pro-Angiogenic Proteins in EOC Cells

To determine whether NGF stimulation increases the expression of pro-angiogenic proteins through a COX-2/PGE 2 -dependent mechanism, EOC cells were pre-incubated with the specific COX-2 inhibitor NS398 $(20 \mu \mathrm{M})$ at a concentration that blocks the NGF-stimulated PGE $_{2}$ increases (Figure S3A), and then EOC cells were stimulated with NGF (100 or $150 \mathrm{ng} / \mathrm{mL}$ ), as was indicated in the Methodology section. The results showed that inhibition of COX-2 prevented the NGF-induced increase in survivin and c-MYC protein levels in all EOC cell lines ( $p<0.05$ Figure 5A-D), as well as the NGF-induced VEGF expression (see Figure 1I). The COX-2 inhibitor did not affect baseline $\beta$-catenin protein levels (Figure 5A-D and Figure S8); however, as expected, the inhibition of COX-2 prevented the NGF-induced $\beta$-catenin/TCF-Lef and MYC transcriptional activity in most cell lines $(p<0.05$; Figure 5E-H).

To confirm that COX-2 modulates the angiogenic potential of EOC cells, we performed an in vitro assay with endothelial cells. Conditioned media from EOC cells stimulated with NGF increased the angiogenic score of endothelial cells ( $p<0.05$; Figure 5I-L). Alternatively, EOC cells pre-treated with COX-2 inhibitor and stimulated with NGF were unable to increase the angiogenic score of EA.hy926 cells compared with the NGF-stimulated group $(p<0.05$ for OVCAR3 cells, $p<0.01$ for SKOV3 cells, and $p<0.001$ in A2780 cells). Also, for culture supernatants from non-tumoral HOSE cells, lower angiogenic scores were observed compared with EOC cells and, moreover, COX-2 inhibition of HOSE cells blocked the NGF-induced increase in angiogenic score (Figure S9).

Taken together, these results demonstrate that the increase in VEGF and the vasculogenic potential of EOC cells stimulated by NGF depends on activation of the COX-2/PGE 2 signaling axis.

\subsection{0. $P G E_{2}$ Stimulation Increases the Expression of Pro-Angiogenic Proteins in EOC Cells}

Because COX-2 inhibition prevents the NGF-mediated increases of all pro-angiogenic proteins evaluated, the effects of stimulating cells with $\mathrm{PGE}_{2}$ were also determined. As shown in Figure 6, PGE $_{2}$ stimulation increased c-MYC and survivin protein levels $(p<0.05$ and $p<0.01$; Figure 6A-D). In addition, $\mathrm{PGE}_{2}$ increased $\beta$-catenin protein levels in only two of four EOC cell lines (Figure S10). However, $\mathrm{PGE}_{2}$ increased $\beta$-catenin/TCF-Lef transcriptional activity in all EOC cell lines $(p<0.05$; Figure 6E-H), as well as VEGF levels in the culture supernatants of these EOC cells $(p<0.05$ and $p<0.01$; Figure 6I-L). Finally, as expected, $\mathrm{PGE}_{2}$ increased MYC transcriptional activity in EOC cells $(p<0.05$, Figure S11). 


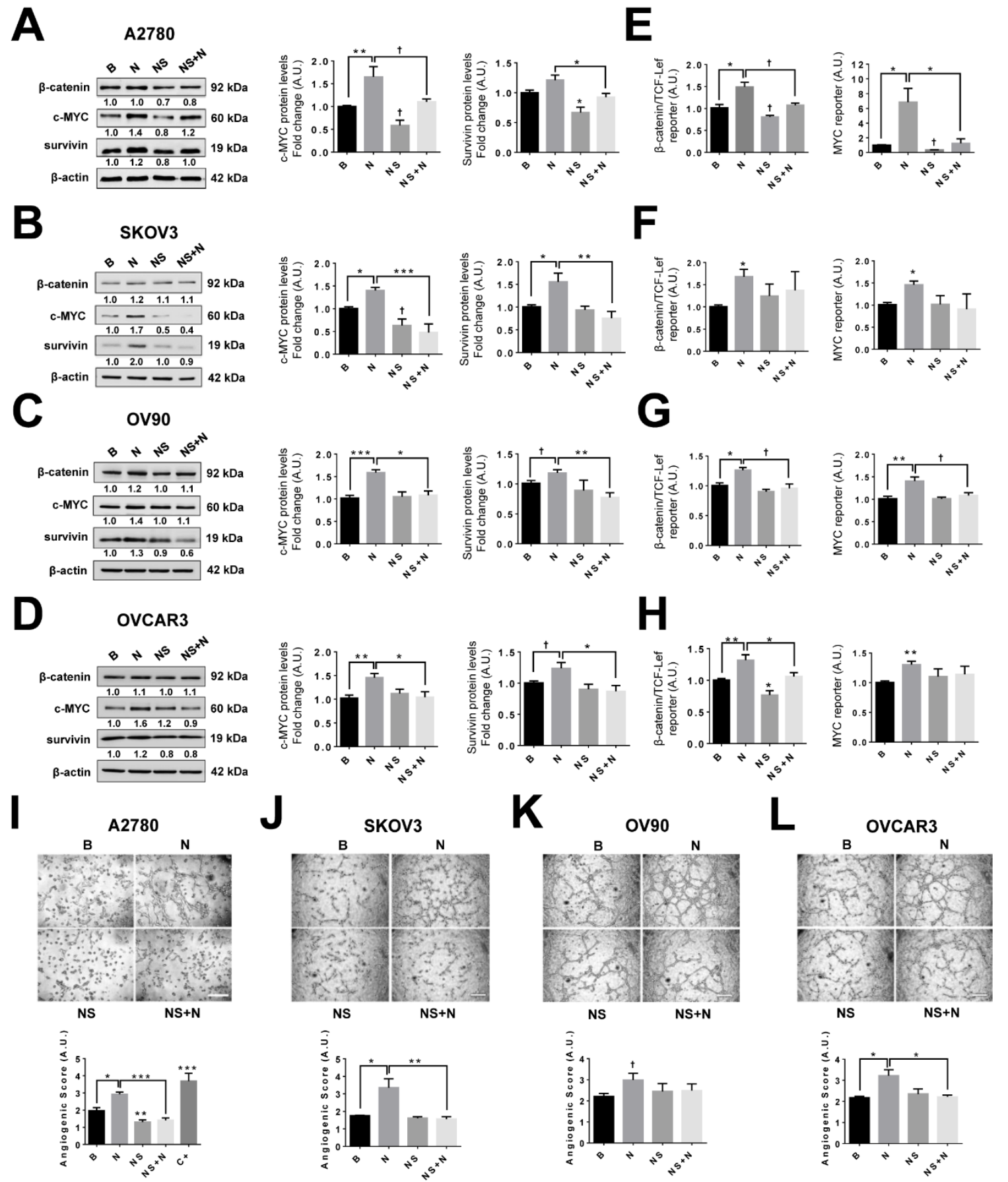

Figure 5. Increased expression of pro-angiogenic proteins stimulated by NGF depends on COX-2/PGE 2 signaling. EOC cells were treated with the COX-2 inhibitor (NS, $20 \mu \mathrm{M}$ ) for $24 \mathrm{~h}$ and then stimulated with NGF (100 or $150 \mathrm{ng} / \mathrm{mL}$ ) during the last 2 h (HOSE, A2780, and SKOV3 cells) or 8 h (OV90 and OVCAR3 cells). (A-D) $\beta$-catenin, c-MYC, and survivin protein levels evaluated by western blotting and a representative image of results (left) with the respective protein/ $\beta$-actin ratios. $n=4$ or more (duplicate). (E-H) $\beta$-catenin/TCF-Lef and MYC transcriptional activity in EOC cells stimulated with NGF either in the absence or presence of the COX-2 inhibitor. (I-L) Representative images and quantification of the angiogenic score of endothelial cells (EA.hy926) stimulated with conditioned medium from EOC cells treated with the COX-2 inhibitor and NGF. Bar $=100 \mu \mathrm{m} . n=4$ (eight pictures per condition). C+: positive control, EAhy926 cells stimulated with VEGF ( $20 \mathrm{ng} / \mathrm{mL}, 8 \mathrm{~h})$. B = basal condition (without stimuli); N = NGF 100 or $150 \mathrm{ng} / \mathrm{mL}$, as described in the methodology section; NS $=$ COX-2 inhibitor (NS398, $20 \mu \mathrm{M}){ }^{*}=p<0.05,{ }^{* *}=p<0.01$, and ${ }^{* * *}=p<0.001$, with respect to basal conditions or as indicated (Kruskal-Wallis test and Dunn's post-test). $+=p<0.05$, with respect to basal conditions or as indicated (Mann-Whitney test). Results are expressed as the mean \pm standard error of the mean (SEM). 
A
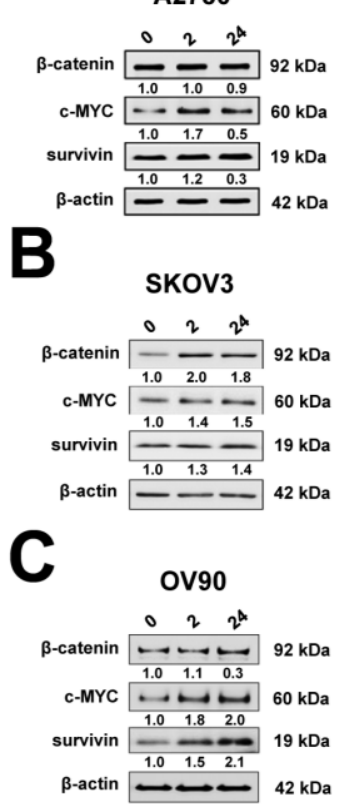

D

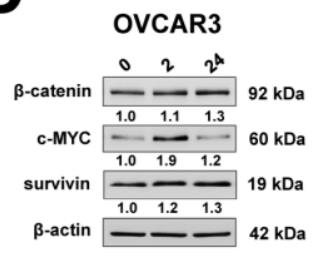

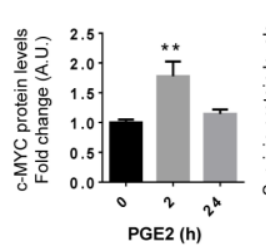
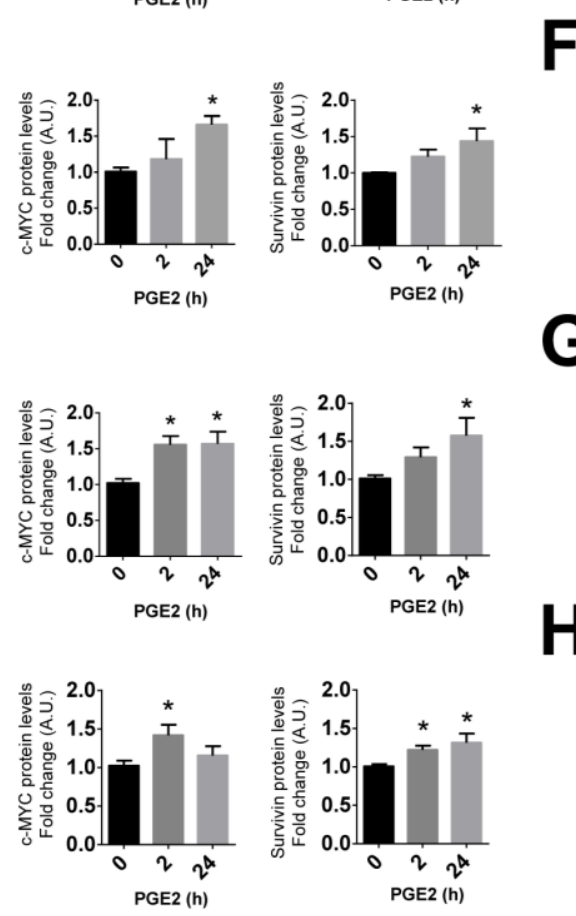
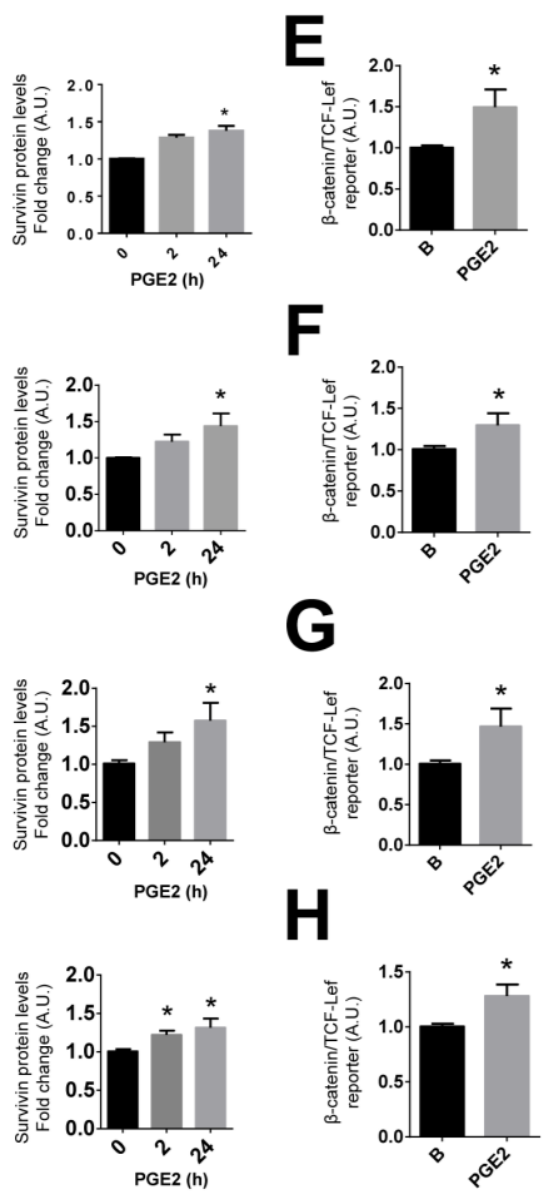
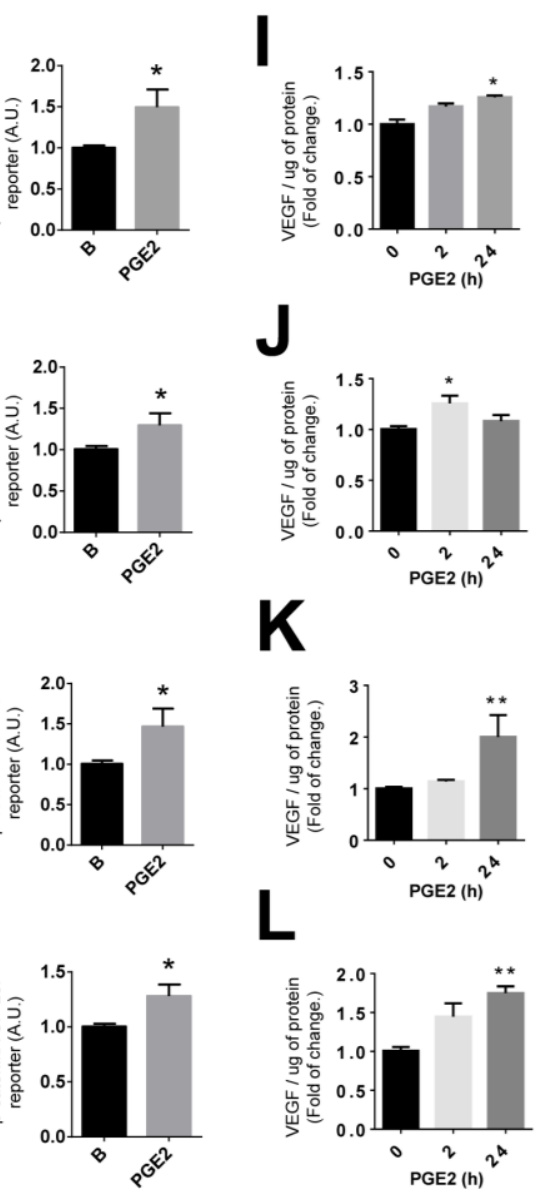

Figure 6. $\mathrm{PGE}_{2}$ increases the abundance of pro-angiogenic proteins in EOC cells. EOC cells were treated with prostaglandin $\mathrm{E} 2\left(\mathrm{PGE}_{2}, 20 \mu \mathrm{M}\right)$ for 2 or $24 \mathrm{~h}$. (A-D) $\beta$-catenin, c-MYC, and survivin protein levels evaluated by western blotting after $\mathrm{PGE}_{2}$ stimulation (with the respective protein/ $\beta$-actin ratios), $n=4$ or more (duplicate). (E-H) $\beta$-catenin/TCF-Lef transcriptional activity after $\mathrm{PGE}_{2}$ stimulation (24 h), $n=4$. (I-L) VEGF protein levels in culture supernatants of EOC cells stimulated with PGE2, $n=4$ in duplicate. ${ }^{*}=p<0.05$ and ${ }^{* *}=p<0.01$ with respect to the baseline condition (Kruskal-Wallis test and Dunn's post-test). Results were expressed as mean \pm standard error of the mean (SEM).

\section{Discussion}

EOC is the leading cause of death due to gynecological neoplasms in developed countries [5]. The high mortality and the poor response to therapies in this pathology $[5,7]$ require a better understanding of the molecular mechanisms implicated in the development of EOC in order to identify new therapeutic targets. Previous results have shown that NGF/TRKA are involved in the progression and angiogenesis in EOC [9]. The current findings reveal that NGF/TRKA enhances expression of the pro-inflammatory enzyme COX-2 and $\mathrm{PGE}_{2}$ secretion in EOC cells. Importantly, we show that $\mathrm{COX}-2 / \mathrm{PGE}_{2}$ signaling regulates the levels of several pro-angiogenic proteins, such as c-MYC, survivin, the $\beta$-catenin/TCF-Lef transcription complex, and VEGF. This suggests that the pro-inflammatory COX-2/PGE 2 axis plays a key role in the progression and dissemination of EOC and, therefore, represents an attractive therapeutic target in this pathology.

NGF is an important pro-tumoral factor, because it not only increases the proliferation of EOC cells $[10,12]$ but also is proposed to function as a direct and indirect angiogenic factor in EOC, given that it increases VEGF secretion in EOC explants $[9,11]$ and can bind to the TRKA receptor in the endothelial cells to promote angiogenesis $[9,12]$. Our results reinforce these previous findings, as stimulation of EOC cell lines with NGF increases VEGF secretion and increases their vasculogenic 
potential. In the present study, we sought to shed light on the cellular mechanism by which NGF increases VEGF secretion. For this reason, we evaluated changes in proteins and transcription factors implicated in increasing VEGF expression in several models of cancer cells, such as c-MYC, $\beta$-catenin, and survivin. Previous reports from our group have shown that NGF increases c-MYC levels in EOC explants [10]; however, the effect of NGF on the other angiogenic proteins mentioned above were unknown. Our results show that NGF increases c-MYC and survivin levels in non-tumoral HOSE and EOC cell lines, as well as the transcriptional activity of MYC and $\beta$-catenin/TCF-Lef in EOC cells. These observations suggest that NGF not only has a pro-angiogenic effect in EOC cells, but may also contribute to the transformation of non-tumoral ovarian epithelial cells.

One interesting point here is that NGF-stimulation increased survivin levels in EOC cells, which has not been described previously. Survivin is an important protein in cancer that favors the survival of tumor cells by inhibiting cell death and promoting cell proliferation [42]. The results obtained in HOSE cells revealed a significant increase in survivin after short stimulation ( $2 \mathrm{~h}$ post-NGF stimulation), whereas in EOC cells the greatest increases in survivin levels were observed after longer time periods ( 8 and $24 \mathrm{~h}$ after NGF stimulation). This difference could be explained by a variety of mechanisms. Survivin is a short-lived protein with a half-life of about $30 \mathrm{~min}$, and proteasome inhibitors greatly stabilize survivin in vivo [43]. In addition, survivin levels increase following EGF stimulation of the ERK-depending pathway for short periods ( 2 and $4 \mathrm{~h}$ ) in beta pancreatic cells. These observations suggest that the rapid increase in survivin could be mediated by NGF-dependent inhibition of proteasome-mediated degradation in ovarian cells. On the other hand, other authors have described that ERK and AKT signaling is required to activate survivin transcription in colorectal cancer cells [44]. Thus, the long-term increase in survivin levels observed in EOC cells mediated by NGF/TRKA could potentially be attributed to an increase in survivin transcription, which was evidenced by an increase in survivin mRNA post-NGF stimulation in ovarian cells (Figure S12).

Because COX-2/PGE 2 signaling has been linked to increases in VEGF in many in vitro models, we determined whether NGF-enhanced expression of pro-angiogenic proteins occurs through activation of the COX-2/PGE 2 system. The overexpression of COX-2 has been shown to be highly relevant in various neoplasms, such as colon and stomach cancers [26,45]. In the present study, as has been described by others [46,47], significantly increased COX-2 immunostaining was observed in EOC tissue, compared with samples from early stages of ovarian cancer. The same pattern was observed at the protein and mRNA levels for COX-2. These results point towards the existence of a correlation between COX-2 overexpression and several clinical variables, such as size, histological type, and tumor grade $[48,49]$. COX-2 overexpression correlates with drug resistance and reduced patient survival [48,49], whereas NGF/TRKA has been implicated in EOC progression [9]. Thus, our results suggest that resistance to chemotherapy and low survival rates of advanced EOC patients might be attributable to elevated levels of COX2 and that use of specific inhibitors could be helpful as part of the EOC therapy.

NGF-induced increases in COX-2 protein and mRNA levels, as well as $\mathrm{PGE}_{2}$ secretion, were observed in EOC cells. In order to determine whether NGF effects on angiogenic proteins (c-MYC, survivin, and VEGF) depended on COX-2/PGE 2 signaling, we evaluated the effects of a COX-2-specific inhibitor and direct stimulation with $\mathrm{PGE}_{2}$. Our results show that pre-treatment of EOC cells with the COX-2 inhibitor precluded augmented expression of all pro-angiogenic proteins induced by NGF. On the other hand, EOC cells stimulated with $\mathrm{PGE}_{2}$ showed an increase in c-MYC, survivin, and VEGF protein levels, and increased $\beta$-catenin/TCF-Lef-dependent transcriptional activity was also detected. Together, these results show that the pro-angiogenic effects of NGF strongly depend on signaling via the COX-2/PGE 2 axis in EOC cells. Somewhat surprisingly, however, NGF-increased VEGF levels were not prevented by pre-treatment with the COX-2 inhibitor for short periods of time (Figure S13). Another crucial point is that NGF increases VEGF in non-tumoral HOSE cells independently of COX-2/PGE 2 signaling, as NGF did not increase COX-2 or $\mathrm{PGE}_{2}$ in this cell type. These results suggest that NGF produces an increase in VEGF in ovarian cells by at least two different 
mechanisms: (1) a rapid increase, independent of the COX-2/PGE 2 axis, perhaps mediated by an increase in VEGF release [50] or a rapid increase in VEGF mRNA, as described in EOC explants [11]; (2) a slower response mediated by $\mathrm{COX}-2 / \mathrm{PGE}_{2}$, which appears to be crucial to increased VEGF expression in EOC cells. This interpretation of the results is favored by the fact that $\mathrm{PGE}_{2}$ needs to be synthesized and released from cells, and then to bind to cell surface membrane receptors, known to be present in ovarian cells [51].

Interestingly, inhibition of endogenous expression of angiogenic proteins was not observed using TRKA or COX-2 inhibitors. For instance, survivin is regulated by several growth factors and their respective receptors, including epidermal growth factor (EGF) and fibroblast growth factor (FGF) in breast cancer cells [36,52]. These growth factors/receptors are present in ovarian cancer cells, so it is possible that survivin could be regulated by growth factors other than NGF, especially in a compensatory manner when NGF is inhibited. Another interesting observation is that COX-1 is aberrantly expressed in ovarian tumors and ovarian cancer, especially in high grade serous ovarian cancer cells $[53,54]$. Thus, under conditions where COX-2 is inhibited, it is possible that levels of pro-angiogenic proteins are maintained thanks to the contribution of COX-1.

To determine whether the inhibition of COX-2/PGE 2 signaling and decreases in VEGF secretion leads to significant changes in the angiogenic potential of EOC cells, we evaluated the behavior of endothelial cells in vasculogenesis assays. Angiogenesis is a complex process that involves different cell types, the extracellular matrix, and humoral components such as growth factors [55]. However, in vitro studies evaluating vasculogenesis induced by different stimuli in endothelial cells, serve to provide insight to the angiogenic potential of cancer cells [56]. The NGF-induced increase in the angiogenic score of EA.hy926 cells was prevented by pre-incubation of EOC cells with the COX-2 inhibitor. This functional assay reinforces our key finding indicating that increases in VEGF due to NGF in EOC are triggered via the COX-2/ $\mathrm{PGE}_{2}$ axis.

In summary (see Figure 7), the present work describes for the first time a connection between NGF and COX-2/PGE 2 signaling in EOC cells. NGF was found to increase levels of the oncogenic proteins survivin, c-MYC, and VEGF, as well as the transcriptional activity of $\beta$-catenin/TCF-Lef and MYC in EOC cells. Moreover, these effects were mediated by the COX-2/PGE 2 axis, highlighting the importance of this connection between inflammation and angiogenesis in EOC. Taken together, our results suggest that inhibition of the $\mathrm{COX}-2 / \mathrm{PGE}_{2}$ axis could be helpful to complement the currently employed anti-angiogenic therapies in EOC. 


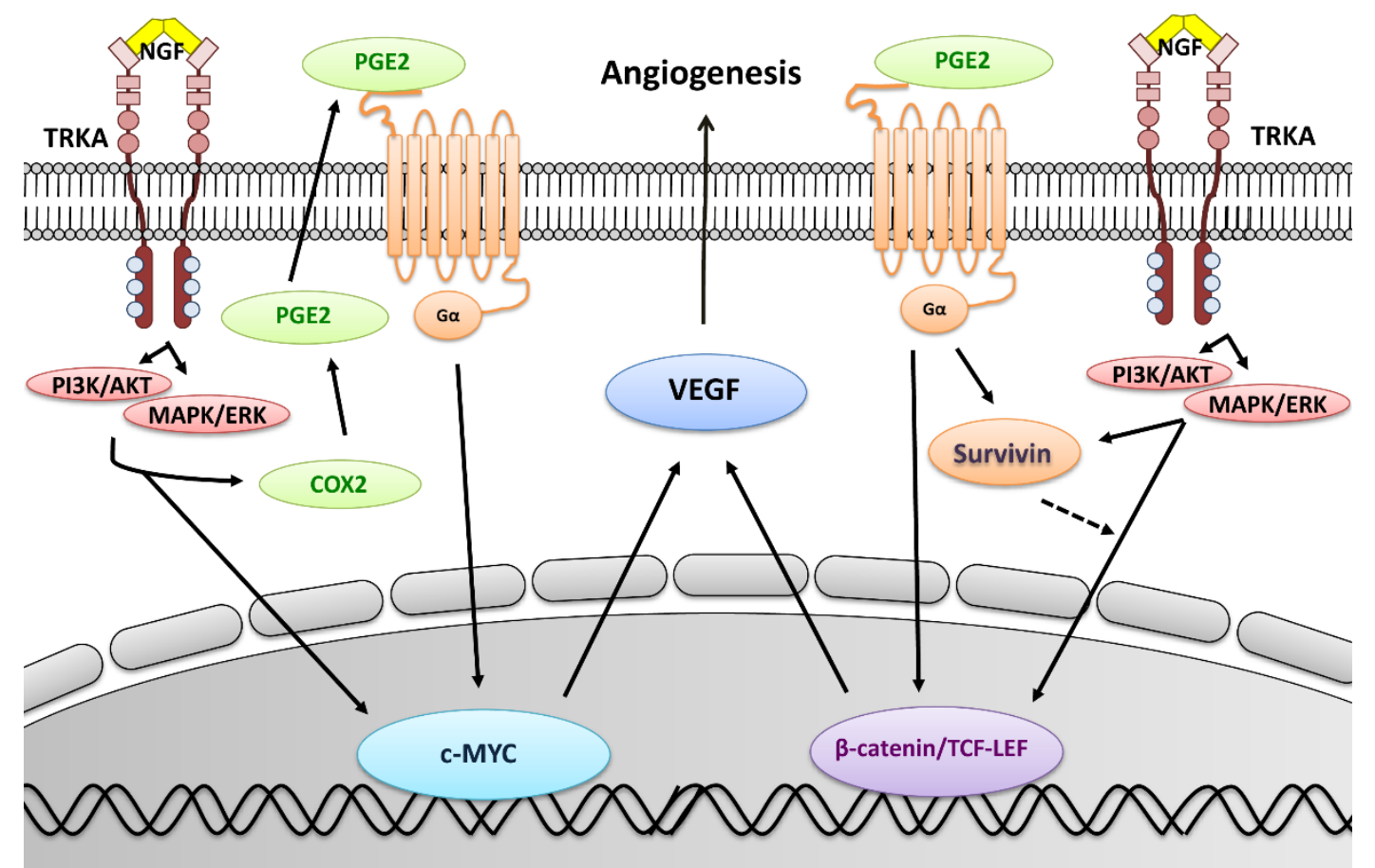

Figure 7. Proposed mechanisms by which NGF increases VEGF expression and angiogenesis in EOC cells. NGF and its high affinity receptor TRKA are overexpressed in EOC cells [9] and activate different signaling pathways, such as phosphoinositide 3-kinase/protein kinase B (PI3K/AKT) and mitogen-activated protein kinase/extracellular signal-regulated kinase (MAPK/ERK) [10,31]. This leads to an increase in COX-2 and prostaglandin $\mathrm{E}_{2}\left(\mathrm{PGE}_{2}\right)$, as well as the activation of c-MYC and $\beta$-catenin/TCF-Lef-dependent transcription, which increases the expression of VEGF in EOC cells (rapid mechanism). Additionally, autocrine/paracrine signaling via $\mathrm{PGE}_{2}$ increases the protein levels and transcriptional activity of c-MYC, as well as the transcriptional activity of $\beta$-catenin/TCF-Lef, to augment VEGF expression (delayed mechanism). On the other hand, NGF/TRKA and $\mathrm{PGE}_{2}$ increase survivin levels, which stimulates $\beta$-catenin/TCF-Lef activity in an amplification loop, as described previously [17], that increases VEGF and therefore the angiogenic potential of EOC cells.

\section{Methods}

\subsection{Tissue Samples}

Ovarian tissue samples were removed surgically from post-menopausal patients at the Hospital Clínico Universidad de Chile. Each patient signed an informed consent approved by the Institutional Ethics Committee (Comité de Ética Hospital Clínico Universidad de Chile, in 18 May 2016), Record $\mathrm{N}^{\circ} 022$, 2016). Sequential Paraffin-embedded samples were classified as inactive normal ovarian tissue samples (IOV, $n=4$ ), serous ovarian tumors (benign tumor, Be-T, and borderline tumor, Bo-T, $n=15$ ), or serous epithelial ovarian cancer $($ EOC $n=10)$, and were used for immunohistochemistry analysis. EOC samples were classified as well (EOC I), moderately (EOC II), or poorly (EOC III) differentiated by an expert pathologist.

\subsection{Cell Culture and Treatments}

Human ovarian surface epithelium (HOSE) cells were donated by Dr. Davie Munroe (NCI, NHI) and human epithelial ovarian cancer cell lines A2780 were obtained from the European Collection of Authenticated Cell Cultures (ECACC). SKOV3, OV90, and NIH-OVCAR3 (OVCAR3) cells were obtained from the American Type Culture Collection (ATCC). A2780 and HOSE cell lines were cultured in Dulbecco's minimal essential medium/Ham F-12 without phenol red (Sigma-Aldrich, St. Louis, MO, USA), whereas SKOV3, OV90, and OVCAR3 cells were cultivated in Roswell Park Memorial Institute 
(RPMI)-1640 medium (Life Technologies, Thermo Fisher Scientific, Carlsbad, CA, USA). Both culture media were supplemented with $10 \%$ fetal bovine serum (FBS) and penicillin/streptomycin $(100 \mu \mathrm{g} / \mathrm{mL}$ and $100 \mathrm{U} / \mathrm{mL}$ ). The human endothelial cell line EA.hy926 was obtained from ATCC Cell Collection and was cultured in Iscove's Modified Dulbecco's Medium (IMDM) (Life Technologies, Thermo Fischer Scientific) supplemented with 10\% FBS. A total of 500,000 cells from both ovarian cell lines were serum-deprived for $24 \mathrm{~h}$ and treated with NGF (Sigma-Aldrich) as indicated: (1) dose-response curves with 50,100, and $150 \mathrm{ng} / \mathrm{mL}$ of NGF in the first experiments and (2) NGF at a concentration of $100 \mathrm{ng} / \mathrm{mL}$ (HOSE, A2780, and OV90 cells) or $150 \mathrm{ng} / \mathrm{mL}$ (SKOV3 and OVCAR3 cells) for the remaining experiments. In addition, EOC cells were treated with a TRKA inhibitor GW441756 $20 \mathrm{nM}$ (Tocris, Bristol, UK), an NGF-neutralizing antibody (Abcam \#ab6199, $5 \mu \mathrm{g} / \mathrm{mL}$, Cambridge, UK), the specific COX-2 inhibitor NS398 (Abcam, $20 \mu \mathrm{M}$ ), or prostaglandin E2 (Sigma, $20 \mu \mathrm{M}$ ) for 2 or $24 \mathrm{~h}$. Cells were pre-incubated with the inhibitors for $1 \mathrm{~h}$ prior to addition of NGF.

\subsection{Immunohistochemistry (IHQ)}

IHQ was performed as previously described [11]. Anti-COX-2 (Cell signaling Technology \#12282; 1:600, Danvers, CO, USA) or anti-survivin antibodies (R\&D Systems \#AF886; 1:500, Minneapolis, MS, USA) were incubated at $4{ }^{\circ} \mathrm{C}$ overnight. For each slide, a negative control incubated only with $2 \%$ phosphate buffered saline-bovine serum albumin (PBS-BSA) without the primary antibody was included. Five to ten microphotographs were obtained with each sample. Immunostaining was semi-quantified by integrated optical density (IOD) analysis of positive cells using the program Image-ProPlus 6.2 (Media Cybernetics, Rockville, MD, USA).

\subsection{Immunocytochemistry (ICQ)}

ICQ was performed as previously described [12]. c-MYC (Cell Signaling \#5605, 1:500) and $\beta$-catenin (BD Transduction Laboratories \#610154, 1:1000, Franklin Lakes, NJ, USA) were detected and IOD values were obtained as described above.

\subsection{Western Blotting}

Nitrocellulose membranes with protein extracts ( 30 or $50 \mu \mathrm{g}$ of total protein) were incubated with either anti-COX-2 (Cell Signaling \#12282, 1:500) or anti-survivin antibodies (R\&D Systems \#AF886) at dilutions of 1:3000 for A2780, SKOV3, OV90, and OVCAR3 cells, and 1:1000 for HOSE cells (because of lower expression in this cell type), anti-c-MYC (\#5605, 1:500), or anti- $\beta$-catenin antibodies (BD Transduction Laboratories \#610154; 1:3000) at $4{ }^{\circ} \mathrm{C}$ overnight. Beta-actin (Sigma \#A2228, 1:10,000) was used as loading control. Human embryonic kidney (HEK)-293 cells transfected with COX-2 or survivin, were used as positive controls. Protein bands were quantified by scanning densitometry of western blots using the software Fiji Image J (developed by National Institutes of Health/University of Wisconsin, WI, USA). Original captures of western blots were included in Supplementary Materials (Figure S14).

\subsection{Total RNA Extraction and RT-PCR}

Total RNA extraction was performed using the phenol-chloroform method. A total of $2 \mu \mathrm{g}$ of RNA was used for reverse transcription, as described previously [57]. COX-2 and glyceraldehyde 3-phosphate dehydrogenase (GAPDH) cDNA amplification were performed by traditional PCR using GoTaq polymerase (Promega, Madison, WI, USA). Survivin amplification was performed by real time PCR using the Brilliant II SybrGreen QPCR master mix (Agilent Technologies, Santa Clara, CA, USA). All primers used are described in Table S1. GAPDH or beta-actin were used as invariant control genes. Sterile water instead of cDNA was added as a negative control for the reactions. 


\section{7. $P G E_{2}$ and VEGF ELISA}

$\mathrm{PGE}_{2}$ and VEGF in culture supernatants were determined with ELISA kits (Abcam \#Ab136948 and R\&D Systems \#DVE00 respectively), according to the manufacturer's instructions.

\section{8. $\beta$-catenin/Tcf-Lef Reporter Assay}

Cells $(450,000)$ were transfected for $8 \mathrm{~h}$ using $0.3 \mu \mathrm{L}$ of ViaFect (Promega) in $50 \mu \mathrm{L}$ of opti-MEM ${ }^{\circledR} \mathrm{I}$ reduced serum media (Thermo Fisher Scientific) and $0.5 \mu \mathrm{g}$ of the following plasmids: (1) pTOP-FLASH (that contains $\beta$-catenin/Tcf-Lef responsive elements), (2) pFOP-FLASH (non-inducible reporter construct), and (3) pPON-FLASH (beta-galactosidase transfection control). Then, cells were deprived of FBS overnight and stimulated the following morning as described in Section 4.2. Cells were lysed and luciferase activity was measured with the Dual luciferase reporter assay system (Promega) according to the manufacturer's instructions. $\mathrm{LiCl} 15 \mathrm{mM}$ was used as a positive control. $\beta$-galactosidase activity of constructs was measured as previously described [58].

\subsection{MYC Reporter Assay}

A total of 30,000 cells in 24-well plates were used. The experiment was performed using the Cignal Myc Reporter Assay Kit (Qiagen, Hilden, Germany), according the manufacturer's instructions.

\subsection{Vasculogenesis Assay}

A total of 10,000 EA.hy926 cells were serum-deprived for $24 \mathrm{~h}$ and then placed in 24-well plates that were coated with $150 \mu \mathrm{L}$ of growth factor reduced, phenol red-free Matrigel (Corning, New York, NY, USA) and $500 \mu \mathrm{L}$ of the different conditioned media from A2780 cells. After $8 \mathrm{~h}$, cells were photographed and the angiogenic score was calculated [59]. This index is based on the morphology of and the connections between endothelial cells and was calculated using the following formula:

Angiogenic Score $=\frac{\mathrm{N}^{\circ} \text { of sprouts }+\left(\mathrm{N}^{\circ} \text { of connected cells }\right) \times 2+\left(\mathrm{N}^{\circ} \text { of polygons }\right) \times 3}{\mathrm{~N}^{\circ} \text { of total cells }}+0,1$, or 2.

\subsection{Statistical Analysis}

Kruskal-Wallis test was used, followed either by Dunn's test, or by the Mann-Whitney test, as appropriate. Results were expressed as mean \pm standard error of the mean (SEM). A value of $p<0.05$ was considered significant. Data analysis was carried out with the GraphPad Prism 6 Program (GraphPad Software, San Diego, CA, USA).

\section{Conclusions}

NGF/TRKA increase the expression of the pro-angiogenic proteins survivin, c-MYC, and VEGF, as well as c-MYC- and $\beta$-catenin/TCF-Lef-dependent transcriptional activity by activating the COX-2/ $\mathrm{PGE}_{2}$ axis in EOC cells. Because EOC cells overexpress NGF/TRKA, which act as proliferative and pro-angiogenic mediators, these results suggest that inhibition of the COX-2/PGE 2 axis represents an attractive therapeutic approach to prevent angiogenesis and therefore tumor growth in EOC.

Supplementary Materials: The following are available online at http://www.mdpi.com/2072-6694/11/12/1970/s1: Table S1: Primer sequences used for traditional and real time PCR, Figure S1: NGF increases COX-2 mRNA in EOC cells, Figure S2: EOC cells respond to TGF- $\beta$ stimulation, increasing COX-2 and PGE 2 , Figure S3: PGE 2 levels in media from different EOC cells before and after COX-2 inhibition, Figure S4: PGE 2 levels after NGF stimulation of HOSE cells, Figure S5: mRNA levels of survivin during EOC progression, Figure S6: Effect of NGF on $\beta$-catenin protein levels in EOC cells, Figure S7: $\beta$-catenin/TCF-Lef and MYC transcriptional activity in A2780 cells, Figure S8: $\beta$-catenin protein levels after NGF stimulation and NS398 treatment of EOC cells, Figure S9: Angiogenic score of HOSE cells after NGF stimulation and NS treatment, Figure S10: $\beta$-catenin protein levels after $\mathrm{PGE}_{2}$ stimulation of EOC cells, Figure S11: $\mathrm{PGE}_{2}$ increases MYC transcriptional activity in EOC cells, Figure S12: Survivin mRNA post-NGF stimulation in ovarian cells, Figure S13: Effect of COX-2 inhibition for short periods of time on VEGF liberation by EOC cells, Figure S14: Panel of original captures. 
Author Contributions: Conceptualization: M.P.G., I.H., A.F.G.Q., and C.R.; formal analysis: M.P.G., I.H., and M.V.-V.; funding acquisition: A.F.G.Q and C.R.; investigation: M.V.-V., R.S., A.H., A.F.G.Q., and C.R.; methodology: M.P.G., I.H., M.V.-V., R.S., A.H., and A.S.; project administration: C.R.; supervision: A.F.G.Q. and C.R.; writing—original draft: M.P.G. and I.H.; writing—review and editing: M.V., A.F.G.Q., and C.R.

Funding: Fondo Nacional de Desarrollo Científico y Tecnológico (FONDECYT) \#1160139 (CRO), Comisión Nacional de Investigación Científica y Tecnológica - Fondo de Financiamiento de Centros de Investigación en Áreas Prioritarias (CONICYT-FONDAP) \#15130011, FONDECYT \#1130250, \#1170925 (AFGQ), CONICYT scholarship \#21150360 (MPG).

Conflicts of Interest: The authors declare no conflicts of interest.

\section{References}

1. Reid, B.M.; Permuth, J.B.; Sellers, T.A. Epidemiology of ovarian cancer: A review. Cancer Biol. Med. 2017, 14, 9-32. [PubMed]

2. World Ovarian Cancer Coalition. The World Ovarian Cancer Coalition Atlas. Global Trends in Incidence, Mortality and Survival. 2018. Available online: https://worldovariancancercoalition.org/wpcontent/uploads/2018/10/THE-WORLD-OVARIAN-CANCER-COALITION-ATLAS-2018.pdf (accessed on 20 November 2019).

3. Cancer Research UK. Ovarian Cancer. Available online: https://www.cancerresearchuk.org/about-cancer/ ovarian-cancer/survival (accessed on 20 November 2019).

4. American Cancer Society Ovarian Cancer, Early Detection, Diagnosis and Staging, Survival Rates for Ovarian Cancer, by Stage. Available online: https://www.cancer.org/cancer/ovarian-cancer/detection-diagnosisstaging/survival-rates.html (accessed on 20 November 2019).

5. Jemal, A.; Bray, F.; Center, M.M.; Ferlay, J.; Ward, E.; Forman, D. Global cancer statistics. CA Cancer J. Clin. 2011, 61, 69-90. [CrossRef] [PubMed]

6. Hennessy, B.T.; Coleman, R.L.; Markman, M. Ovarian cancer. Lancet 2009, 374, 1371-1382. [CrossRef]

7. Doubeni, C.A.; Doubeni, A.R.; Myers, A.E. Diagnosis and Management of Ovarian Cancer. Am. Fam. Physician 2016, 93, 937-944.

8. Duncan, T.J.; Al-Attar, A.; Rolland, P.; Scott, I.V.; Deen, S.; Liu, D.T.; Spendlove, I.; Durrant, L.G. Vascular endothelial growth factor expression in ovarian cancer: A model for targeted use of novel therapies? Clin. Cancer Res. 2008, 14, 3030-3035. [CrossRef]

9. Tapia, V.; Gabler, F.; Munoz, M.; Yazigi, R.; Paredes, A.; Selman, A.; Vega, M.; Romero, C. Tyrosine kinase A receptor (trkA): A potential marker in epithelial ovarian cancer. Gynecol. Oncol. 2011, 121, 13-23. [CrossRef]

10. Urzua, U.; Tapia, V.; Geraldo, M.P.; Selman, A.; Vega, M.; Romero, C. Nerve growth factor stimulates cellular proliferation of human epithelial ovarian cancer. Horm. Metab. Res. 2012, 44, 656-661. [CrossRef]

11. Campos, X.; Munoz, Y.; Selman, A.; Yazigi, R.; Moyano, L.; Weinstein-Oppenheimer, C.; Lara, H.E.; Romero, C. Nerve growth factor and its high-affinity receptor trkA participate in the control of vascular endothelial growth factor expression in epithelial ovarian cancer. Gynecol. Oncol. 2007, 104, 168-175. [CrossRef]

12. Garrido, M.P.; Vera, C.; Vega, M.; Quest, A.F.G.; Romero, C. Metformin prevents nerve growth factor-dependent proliferative and proangiogenic effects in epithelial ovarian cancer cells and endothelial cells. Ther. Adv. Med. Oncol. 2018, 10, 1758835918770984. [CrossRef]

13. Eibl, G.; Bruemmer, D.; Okada, Y.; Duffy, J.P.; Law, R.E.; Reber, H.A.; Hines, O.J. PGE (2) is generated by specific COX-2 activity and increases VEGF production in COX-2-Expressing human pancreatic cancer cells. Biochem. Biophys. Res. Commun. 2003, 306, 887-897. [CrossRef]

14. Ding, Y.B.; Shi, R.H.; Tong, J.D.; Li, X.Y.; Zhang, G.X.; Xiao, W.M.; Yang, J.G.; Bao, Y.; Wu, J.; Yan, Z.G.; et al. PGE2 up-regulates vascular endothelial growth factor expression in MKN28 gastric cancer cells via epidermal growth factor receptor signaling system. Exp. Oncol. 2005, 27, 108-113. [PubMed]

15. Wang, X.; Klein, R.D. Prostaglandin E2 induces vascular endothelial growth factor secretion in prostate cancer cells through EP2 receptor-mediated cAMP pathway. Mol. Carcinog. 2007, 46, 912-923. [CrossRef] [PubMed]

16. Jain, S.; Chakraborty, G.; Raja, R.; Kale, S.; Kundu, G.C. Prostaglandin E2 regulates tumor angiogenesis in prostate cancer. Cancer Res. 2008, 68, 7750-7759. [CrossRef] [PubMed] 
17. Fernandez, J.G.; Rodriguez, D.A.; Valenzuela, M.; Calderon, C.; Urzua, U.; Munroe, D.; Rosas, C.; Lemus, D.; Diaz, N.; Wright, M.C.; et al. Survivin expression promotes VEGF-induced tumor angiogenesis via PI3K/Akt enhanced beta-catenin/Tcf-Lef dependent transcription. Mol. Cancer 2014, 13, 209. [CrossRef] [PubMed]

18. Chun, K.S.; Langenbach, R. The prostaglandin E2 receptor, EP2, regulates survivin expression via an EGFR/STAT3 pathway in UVB-exposed mouse skin. Mol. Carcinog. 2011, 50, 439-448. [CrossRef]

19. Olsen, J.J.; Pohl, S.O.; Deshmukh, A.; Visweswaran, M.; Ward, N.C.; Arfuso, F.; Agostino, M.; Dharmarajan, A. The Role of Wnt Signalling in Angiogenesis. Clin. Biochem. Rev. 2017, 38, 131-142.

20. Shao, J.; Lee, S.B.; Guo, H.; Evers, B.M.; Sheng, H. Prostaglandin E2 stimulates the growth of colon cancer cells via induction of amphiregulin. Cancer Res. 2003, 63, 5218-5223.

21. Bazzani, L.; Donnini, S.; Finetti, F.; Christofori, G.; Ziche, M. PGE2/EP3/SRC signaling induces EGFR nuclear translocation and growth through EGFR ligands release in lung adenocarcinoma cells. Oncotarget 2017, 8 , 31270-31287. [CrossRef]

22. Sobolewski, C.; Cerella, C.; Dicato, M.; Diederich, M. Cox-2 inhibitors induce early c-Myc downregulation and lead to expression of differentiation markers in leukemia cells. Cell Cycle 2011, 10, 2978-2993. [CrossRef]

23. Morita, I. Distinct functions of COX-1 and COX-2. Prostaglandins Other Lipid Mediat. 2002, 68, 165-175. [CrossRef]

24. Rouzer, C.A.; Marnett, L.J. Cyclooxygenases: Structural and functional insights. J. Lipid Res. 2009, 50, $29-34$. [CrossRef] [PubMed]

25. Vane, J.R.; Bakhle, Y.S.; Botting, R.M. Cyclooxygenases 1 and 2. Annu. Rev. Pharm. Toxicol. 1998, 38, 97-120. [CrossRef] [PubMed]

26. Ristimaki, A.; Honkanen, N.; Jankala, H.; Sipponen, P.; Harkonen, M. Expression of cyclooxygenase-2 in human gastric carcinoma. Cancer Res. 1997, 57, 1276-1280. [PubMed]

27. Parrett, M.; Harris, R.; Joarder, F.; Ross, M.; Clausen, K.; Robertson, F. Cyclooxygenase-2 gene expression in human breast cancer. Int. J. Oncol. 1997, 10, 503-507. [CrossRef] [PubMed]

28. Kern, M.A.; Haugg, A.M.; Koch, A.F.; Schilling, T.; Breuhahn, K.; Walczak, H.; Fleischer, B.; Trautwein, C.; Michalski, C.; Schulze-Bergkamen, H.; et al. Cyclooxygenase-2 inhibition induces apoptosis signaling via death receptors and mitochondria in hepatocellular carcinoma. Cancer Res. 2006, 66, 7059-7066. [CrossRef] [PubMed]

29. Sasaki, E.; Tominaga, K.; Watanabe, T.; Fujiwara, Y.; Oshitani, N.; Matsumoto, T.; Higuchi, K.; Tarnawski, A.S.; Arakawa, T. COX-2 is essential for EGF induction of cell proliferation in gastric RGM1 cells. Dig. Dis. Sci. 2003, 48, 2257-2262. [CrossRef]

30. Cheng, A.S.; Chan, H.L.; To, K.F.; Leung, W.K.; Chan, K.K.; Liew, C.T.; Sung, J.J. Cyclooxygenase-2 pathway correlates with vascular endothelial growth factor expression and tumor angiogenesis in hepatitis B virus-associated hepatocellular carcinoma. Int. J. Oncol. 2004, 24, 853-860. [CrossRef]

31. Reichardt, L.F. Neurotrophin-regulated signalling pathways. Philos. Trans. R. Soc. 2006, 361, 1545-1564. [CrossRef]

32. Pai, R.; Szabo, I.L.; Soreghan, B.A.; Atay, S.; Kawanaka, H.; Tarnawski, A.S. PGE(2) stimulates VEGF expression in endothelial cells via ERK2/JNK1 signaling pathways. Biochem. Biophys. Res. Commun. 2001, 286, 923-928. [CrossRef]

33. Baker, V.V.; Borst, M.P.; Dixon, D.; Hatch, K.D.; Shingleton, H.M.; Miller, D. c-myc amplification in ovarian cancer. Gynecol. Oncol. 1990, 38, 340-342. [CrossRef]

34. Gatcliffe, T.A.; Monk, B.J.; Planutis, K.; Holcombe, R.F. Wnt signaling in ovarian tumorigenesis. Int. J. Gynecol. Cancer 2008, 18, 954-962. [CrossRef] [PubMed]

35. Rask, K.; Nilsson, A.; Brannstrom, M.; Carlsson, P.; Hellberg, P.; Janson, P.O.; Hedin, L.; Sundfeldt, K. Wnt-signalling pathway in ovarian epithelial tumours: Increased expression of beta-catenin and GSK3beta. Br. J. Cancer 2003, 89, 1298-1304. [CrossRef] [PubMed]

36. Cosgrave, N.; Hill, A.D.; Young, L.S. Growth factor-dependent regulation of survivin by c-myc in human breast cancer. J. Mol. Endocrinol. 2006, 37, 377-390. [CrossRef] [PubMed]

37. Baudino, T.A.; McKay, C.; Pendeville-Samain, H.; Nilsson, J.A.; Maclean, K.H.; White, E.L.; Davis, A.C.; Ihle, J.N.; Cleveland, J.L. c-Myc is essential for vasculogenesis and angiogenesis during development and tumor progression. Genes Dev. 2002, 16, 2530-2543. [CrossRef] [PubMed]

38. Chen, X.; Duan, N.; Zhang, C.; Zhang, W. Survivin and Tumorigenesis: Molecular Mechanisms and Therapeutic Strategies. J. Cancer 2016, 7, 314-323. [CrossRef] [PubMed] 
39. Sanhueza, C.; Wehinger, S.; Castillo Bennett, J.; Valenzuela, M.; Owen, G.I.; Quest, A.F. The twisted survivin connection to angiogenesis. Mol. Cancer 2015, 14, 198. [CrossRef] [PubMed]

40. Fang, L.; Chang, H.M.; Cheng, J.C.; Leung, P.C.; Sun, Y.P. TGF-beta1 induces COX-2 expression and PGE2 production in human granulosa cells through Smad signaling pathways. J. Clin. Endocrinol. Metab. 2014, 99, E1217-E1226. [CrossRef]

41. Chen, L.; Liang, L.; Yan, X.; Liu, N.; Gong, L.; Pan, S.; Lin, F.; Zhang, Q.; Zhao, H.; Zheng, F. Survivin status affects prognosis and chemosensitivity in epithelial ovarian cancer. Int. J. Gynecol. Cancer 2013, 23, 256-263. [CrossRef]

42. Mita, A.C.; Mita, M.M.; Nawrocki, S.T.; Giles, F.J. Survivin: Key regulator of mitosis and apoptosis and novel target for cancer therapeutics. Clin. Cancer Res. 2008, 14, 5000-5005. [CrossRef]

43. Zhao, J.; Tenev, T.; Martins, L.M.; Downward, J.; Lemoine, N.R. The ubiquitin-proteasome pathway regulates survivin degradation in a cell cycle-dependent manner. J. Cell. Sci. 2000, 113 Pt 23, 4363-4371.

44. Ye, Q.; Cai, W.; Zheng, Y.; Evers, B.M.; She, Q.B. ERK and AKT signaling cooperate to translationally regulate survivin expression for metastatic progression of colorectal cancer. Oncogene 2014, 33, 1828-1839. [CrossRef] [PubMed]

45. Kargman, S.L.; O’Neill, G.P.; Vickers, P.J.; Evans, J.F.; Mancini, J.A.; Jothy, S. Expression of prostaglandin G/H synthase-1 and -2 protein in human colon cancer. Cancer Res. 1995, 55, 2556-2559. [PubMed]

46. Denkert, C.; Kobel, M.; Pest, S.; Koch, I.; Berger, S.; Schwabe, M.; Siegert, A.; Reles, A.; Klosterhalfen, B.; Hauptmann, S. Expression of cyclooxygenase 2 is an independent prognostic factor in human ovarian carcinoma. Am. J. Pathol. 2002, 160, 893-903. [CrossRef]

47. Dore, M.; Cote, L.C.; Mitchell, A.; Sirois, J. Expression of prostaglandin G/H synthase type 1, but not type 2, in human ovarian adenocarcinomas. J. Histochem. Cytochem. 1998, 46, 77-84. [CrossRef] [PubMed]

48. Juuti, A.; Louhimo, J.; Nordling, S.; Ristimaki, A.; Haglund, C. Cyclooxygenase-2 expression correlates with poor prognosis in pancreatic cancer. J. Clin. Pathol. 2006, 59, 382-386. [CrossRef] [PubMed]

49. Nozoe, T.; Ezaki, T.; Kabashima, A.; Baba, H.; Maehara, Y. Significance of immunohistochemical expression of cyclooxygenase-2 in squamous cell carcinoma of the esophagus. Am. J. Surg. 2005, 189, 110-115. [CrossRef] [PubMed]

50. Hoier, B.; Prats, C.; Qvortrup, K.; Pilegaard, H.; Bangsbo, J.; Hellsten, Y. Subcellular localization and mechanism of secretion of vascular endothelial growth factor in human skeletal muscle. FASEB J. 2013, 27, 3496-3504. [CrossRef]

51. Rask, K.; Zhu, Y.; Wang, W.; Hedin, L.; Sundfeldt, K. Ovarian epithelial cancer: A role for PGE2-synthesis and signalling in malignant transformation and progression. Mol. Cancer 2006, 5, 62. [CrossRef]

52. Asanuma, H.; Torigoe, T.; Kamiguchi, K.; Hirohashi, Y.; Ohmura, T.; Hirata, K.; Sato, M.; Sato, N. Survivin expression is regulated by coexpression of human epidermal growth factor receptor 2 and epidermal growth factor receptor via phosphatidylinositol 3-kinase/AKT signaling pathway in breast cancer cells. Cancer Res. 2005, 65, 11018-11025. [CrossRef]

53. Daikoku, T.; Wang, D.; Tranguch, S.; Morrow, J.D.; Orsulic, S.; DuBois, R.N.; Dey, S.K. Cyclooxygenase-1 is a potential target for prevention and treatment of ovarian epithelial cancer. Cancer Res. 2005, 65, 3735-3744. [CrossRef]

54. Wilson, A.J.; Fadare, O.; Beeghly-Fadiel, A.; Son, D.S.; Liu, Q.; Zhao, S.; Saskowski, J.; Uddin, M.J.; Daniel, C.; Crews, B.; et al. Aberrant over-expression of COX-1 intersects multiple pro-tumorigenic pathways in high-grade serous ovarian cancer. Oncotarget 2015, 6, 21353-21368. [CrossRef] [PubMed]

55. Shahid, I.; AlMalki, W.; AlRabia, M.; Ahmed, M.; Imam, M.; Saifullah, M.; Hafeez, M. Chapter: Recent Advances in Angiogenesis Assessment Methods and Their Clinical Applications. In Physiologic and Pathologic Angiogenesis-Signaling Mechanisms and Targeted Therapy; InTechOpen, Ed.; 2017. Available online: https: //www.intechopen.com/books/physiologic-and-pathologic-angiogenesis-signaling-mechanisms-andtargeted-therapy/recent-advances-in-angiogenesis-assessment-methods-and-their-clinical-applications (accessed on 20 November 2019).

56. Sanz-Nogues, C.; O’Brien, T. In vitro models for assessing therapeutic angiogenesis. Drug Discov. Today 2016, 21, 1495-1503. [CrossRef] [PubMed]

57. Kohan-Ivani, K.; Gabler, F.; Selman, A.; Vega, M.; Romero, C. Role of dihydrotestosterone (DHT) on TGF-beta1 signaling pathway in epithelial ovarian cancer cells. J. Cancer Res. Clin. Oncol. 2016, 142, 47-58. [CrossRef] [PubMed] 
58. Rodriguez, D.A.; Tapia, J.C.; Fernandez, J.G.; Torres, V.A.; Munoz, N.; Galleguillos, D.; Leyton, L.; Quest, A.F. Caveolin-1-mediated suppression of cyclooxygenase-2 via a beta-catenin-Tcf/Lef-dependent transcriptional mechanism reduced prostaglandin E2 production and survivin expression. Mol. Biol. Cell 2009, 20, 2297-2310. [CrossRef]

59. Aranda, E.; Owen, G.I. A semi-quantitative assay to screen for angiogenic compounds and compounds with angiogenic potential using the EA. hy926 endothelial cell line. Biol. Res. 2009, 42, 377-389. [CrossRef]

(c) (1)

(C) 2019 by the authors. Licensee MDPI, Basel, Switzerland. This article is an open access article distributed under the terms and conditions of the Creative Commons Attribution (CC BY) license (http://creativecommons.org/licenses/by/4.0/). 